\title{
A Model of Net Amino Acid Absorption and Utilization by the Portal-Drained Viscera of the Lactating Dairy Cow
}

\author{
M. D. Hanigan, ${ }^{1}$ C. K. Reynolds, ${ }^{2, \star}$ D. J. Humphries, ${ }^{2}$ B. Lupoli, ${ }^{2}$ and J. D. Sutton ${ }^{2}$ \\ 'Land O' Lakes, Inc., Gray Summit, MO 63039 \\ ${ }^{2}$ Centre for Dairy Research, School of Agriculture, Policy and Development, \\ The University of Reading, Berkshire RG6 6AR, UK
}

\section{ABSTRACT}

A more complete understanding of amino acid (AA) metabolism by the various tissues of the body is required to improve upon current systems for predicting the use of absorbed AA. The objective of this work was to construct and parameterize a model of net removal of AA by the portal-drained viscera (PDV). Six cows were prepared with arterial, portal, and hepatic catheters and infused abomasally with $0,200,400$, or $600 \mathrm{~g}$ of casein daily. Casein infusion increased milk yield quadratically and tended to increase milk protein yield quadratically. Arterial concentrations of a number of essential AA increased linearly with respect to infusion amount. When infused casein was assumed to have a true digestion coefficient of 0.95 , the minimum likely true digestion coefficient for noninfused duodenal protein was found to be 0.80 . Net PDV use of AA appeared to be linearly related to total supply (arterial plus absorption), and extraction percentages ranged from 0.5 to $7.25 \%$ for essential AA. Prediction errors for portal vein AA concentrations ranged from 4 to $9 \%$ of the observed mean concentrations. Removal of AA by PDV represented approximately $33 \%$ of total postabsorptive catabolic use, including use during absorption but excluding use for milk protein synthesis, and was apparently adequate to support endogenous $\mathrm{N}$ losses in feces of $18.4 \mathrm{~g} / \mathrm{d}$. As $69 \%$ of this use was from arterial blood, increased PDV catabolism of AA in part represents increased absorption of AA in excess of amounts required by other body tissues. Based on the present model, increased anabolic use of AA in the mammary and other tissues would reduce the catabolic use of AA by the PDV.

(Key words: portal-drained viscera, amino acids, cattle, net removal)

Received March 16, 2004.

Accepted August 4, 2004.

Corresponding author: M. D. Hanigan; e-mail: MHanigan@ LandOLakes.com.

*Current address: Department of Animal Sciences, The Ohio State University, OARDC, 1680 Madison Avenue, Wooster, OH 44691.
Abbreviation key: $\mathbf{A s x}=$ Asp plus Asn, BCAA = branched chain AA, EAA = essential AA, GI = gastrointestinal, Glx = Glu plus Gln, NAN = nonammonia nitrogen, $\mathbf{P D V}=$ portal-drained viscera .

\section{INTRODUCTION}

Successful development of a predictive model of wholeanimal AA metabolism requires the integration of knowledge related to a number of processes; including at least digestive and metabolic events occurring within gastrointestinal (GI), hepatic, muscle, and mammary tissues. Modeling efforts have been undertaken to describe ruminal (Dijkstra et al., 1992; O'Connor et al., 1993; NRC, 2001), hepatic (Hanigan et al., 2003), and mammary (Hanigan et al., 2001a, b) tissue metabolism. Although significant effort has been expended on modeling nutrient flows within the gut lumen (Russell et al., 1992; Sniffen et al., 1992; Rulquin et al., 1998; NRC, 2001), there has been little effort directed toward modeling AA metabolism within the portal-drained viscera (PDV: the GI tract, pancreas, spleen, and associated adipose tissue). The PDV represents a heterogeneous collection of tissues responsible for a number of critical functions, including the digestion of protein and absorption of AA; it has a high rate of metabolism and protein turnover and accounts for a large proportion of body AA use. For these reasons, appropriate representation of PDV AA metabolism is needed to predict postabsorptive AA supply.

Examination of PDV AA metabolism in vivo requires a combination of abomasal and ileal cannulas to measure AA disappearance from the lumen of the small intestine and arterial and portal vein catheters to measure AA appearance in the portal vein. Although duodenal cannulation and PDV catheterization have been successfully undertaken in lactating dairy cows, ileal cannulation and insertion is more problematic (Berthiaume et al., 2001). Nonlactating sheep have been successfully prepared simultaneously with duodenal and ileal cannula combined with PDV catheterization (Tagari and Bergman, 1978), and animals with duodenal and ileal cannulas have been paired with separate animals that have 
PDV catheters, to delineate AA metabolism of the PDV and mesenteric drained viscera in sheep (MacRae et al., 1997b) and apparently in cattle (Berthiaume et al., 2001). However, due to animal variation, the paired animal approach requires significantly more animals to achieve an acceptable level of confidence in the calculated values.

Based on available data comparing small intestinal disappearance and net portal vein appearance, it would appear that the PDV removes significant quantities of absorbed AA on a net basis (Tagari and Bergman, 1978; MacRae et al., 1997b; Berthiaume et al., 2001), and thus failure to represent that loss in a whole animal model would result in biased predictions of AA supply. A model of PDV AA metabolism should allow a more robust evaluation of experiments where GI cannulation and visceral catheterization are used by accounting for animal-toanimal variation in arterial and duodenal nutrient fluxes. Integration of these various pieces of information should allow present deficiencies in whole-animal models with respect to PDV losses to be represented. The first step in such an effort is to describe use by the tissue with respect to varying supply. Previous work in growing cattle has measured the net response of PDV $\alpha$-amino $\mathrm{N}$ (Guerino et al., 1991) absorption to abomasal infusion of casein, but, to our knowledge, similar data on the net recovery of abomasally infused casein as increased net absorption of AA are not available for lactating dairy cows.

Therefore, our objective was to measure the effects of incremental abomasal casein infusion on net absorption and metabolism of AA by the PDV and liver, and to use those data to construct a model of net AA absorption and metabolism by the PDV.

\section{MATERIALS AND METHODS}

\section{Cows and Diets}

All animal procedures used were licensed and regulated by the UK Home Office under the Animals (Scientific Procedures) Act of 1986. Six lactating HolsteinFriesian cows were surgically fitted with catheters enabling measurements of splanchnic metabolism (Huntington, 1989) in the first 2 to $3 \mathrm{wk}$ (mean $19 \mathrm{~d}$ ) of their second (5 cows) or third lactation. In addition, their right carotid artery was elevated to a subcutaneous position to enable temporary catheterization if needed. Rumen cannulas were subsequently established after completion of an initial experiment (Reynolds et al., 1995) and at least $8 \mathrm{wk}$ before the beginning of the present experiment. Cows were not pregnant and averaged $611 \mathrm{~kg} \mathrm{BW}$ and 321 DIM when the present experiment began. Cows were housed in individual tie stalls on rubber mats with wood shavings as bedding. They were tethered to feed mangers using head halters and had constant access to
Table 1. Inclusion rate and composition (\% of DM) of the forages and concentrate mixture.

\begin{tabular}{lllll}
\hline Component & $\begin{array}{l}\text { Grass } \\
\text { silage }\end{array}$ & $\begin{array}{l}\text { Grass } \\
\text { pellets }\end{array}$ & Concentrate & $\begin{array}{c}\text { Total } \\
\text { ration }\end{array}$ \\
\hline $\begin{array}{l}\text { Inclusion rate }(\%) \\
\text { Composition }\end{array}$ & 20 & 20 & 60 & 100 \\
Nitrogen & 2.05 & 2.36 & 2.63 & \\
Starch & $\ldots$ & $\ldots$ & 42.1 & 2.46 \\
NDF & 49.0 & 49.1 & 17.0 & 29.2 \\
ADF & 32.4 & 31.0 & 9.2 & 18.2 \\
Ash & 9.06 & 8.01 & 6.68 & 7.42 \\
\hline
\end{tabular}

water and trace-mineralized salt blocks. The barn had translucent roofing to allow natural lighting and was artificially lit from approximately 0600 to $1800 \mathrm{~h}$.

Cows were fed a TMR containing, on a DM basis, $20 \%$ grass silage, $20 \%$ dehydrated grass pellets, and $60 \%$ concentrates. The ration was formulated to be similar to a low-protein, grass silage-based ration fed during the previous experiment conducted using these cows (Reynolds et al., 1995) and other studies of milk protein response to supplemental amino acid supply at Reading (Metcalf et al., 1996), with 2 exceptions. First, the protein content of the concentrate was increased to a moderate level by adding soybean meal. (Tables 1 and 2). Second, $50 \%$ of the amount of grass silage DM was replaced with a commercial grass pellet to allow abomasal infusion via the rumen cannula. When grass silage was the only forage source in the ration, the rumen mat was so extensive and impenetrable that it was impossible to maintain a line into the abomasum, no matter how large a flange was attached to the infusion line and inserted past the omasal pillar. The amount of DM offered was reduced

Table 2. Formulation of the concentrate portion of the ration.

\begin{tabular}{|c|c|}
\hline Ingredient & $\%$ of $\mathrm{DM}$ \\
\hline Barley & 46.6 \\
\hline Wheat & 7.8 \\
\hline Maize & 9.3 \\
\hline Molassed sugar beet feed & 8.5 \\
\hline Molassine meal $^{1}$ & 5.5 \\
\hline Soybean meal, solvent-extracted, $54 \% \mathrm{CP}$ & 12.4 \\
\hline Cassava & 3.6 \\
\hline $\mathrm{NaOH}$-treated straw $^{2}$ & 3.6 \\
\hline Sodium bicarbonate & 1.0 \\
\hline Mineral mix $^{3}$ & 1.6 \\
\hline
\end{tabular}

${ }^{1}$ Molasses impregnated palm kernel meal and straw (Rumenco, Burton on Trent, UK). Labeled as containing $375 \mathrm{~g}$ of molasses, 250 $\mathrm{g}$ of ash, $75 \mathrm{~g}$ of CP, $75 \mathrm{~g}$ of crude fiber, and $6 \mathrm{~g}$ of oil per $\mathrm{kg}$ of DM.

${ }^{2}$ Nutritionally improved straw (Unitrition, Selby, UK).

${ }^{3}$ Labeled as containing $180 \mathrm{~g}$ of calcium (as dicalcium phosphate and limestone), $120 \mathrm{~g}$ of phosphorus (as dicalcium phosphate), $50 \mathrm{~g}$ of magnesium (as magnesium oxide and magnesium phosphate), 1.5 $\mathrm{g}$ of copper (as copper sulfate), $0.015 \mathrm{~g}$ of selenium (as sodium selenite), $380 \mathrm{IU}$ of vitamin A, $80 \mathrm{IU}$ of vitamin D3, and $550 \mathrm{IU}$ of vitamin $\mathrm{E}$ per kg. 
to $95 \%$ of average ad libitum DMI for the week preceding the first abomasal infusion, then held constant for the remainder of the experiment in an attempt to minimize changes in DMI over the course of the experiment. Daily rations were fed as equal meals, provided hourly using automatic feeders. Cows were milked at 0630 and $1730 \mathrm{~h}$.

\section{Experimental Procedures}

The experimental design was a $6 \times 4$ Latin Rectangle design, based on two $4 \times 4$ Latin Squares balanced for carryover effects, each with a column (cow) removed and using four 3 -wk periods. Starting on d 12 of each period, cows received a 10-d abomasal infusion of $12 \mathrm{~L} / \mathrm{d}$ of water as a control (0) or 200,400, or $600 \mathrm{~g} / \mathrm{d}$ (as fed) of sodium caseinate ( $88 \%$ protein, as fed basis) suspended in $12 \mathrm{~L}$ of water using an industrial homogenizer. Daily infusions were given over 23 to $24 \mathrm{~h}$, beginning after the afternoon milking as described previously for abomasal infusions of AA (Aikman et al., 2002).

Milk yields were recorded and milk samples taken at each milking throughout abomasal infusion periods. Milk samples were treated with a preservative $(1 \mathrm{mg}$ of potassium dichromate/mL; Lactabs, Thompson and Capper, Runcorn, UK) and stored at 2 to $4^{\circ} \mathrm{C}$ until analyzed for lactose, fat, and protein concentrations by infrared analysis (Foss Electric Ltd., UK). Feed orts were removed at $0715 \mathrm{~h}$, and samples of feed and orts were analyzed for DM content daily. Daily feed samples were frozen and composited for each experimental period and stored frozen until dried at $60^{\circ} \mathrm{C}$, ground, and analyzed for chemical composition (Table 2) using standard UK analytical procedures (Statutory Instruments, 1982).

\section{Net Flux Measurements}

Measurements of net splanchnic metabolism were obtained on the last day of each abomasal infusion period, as described previously for other studies at Reading (Benson et al., 2002; Reynolds et al., 2003). Six simultaneous heparinized blood sample sets were obtained at hourly intervals from the mesenteric artery catheter and the portal and hepatic vein catheters, beginning at 0730 $\mathrm{h}$ and ending at $1230 \mathrm{~h}$. Blood flow was measured by downstream dilution of $\mathrm{p}$-aminohippurate infused into a mesenteric vein beginning at $0630 \mathrm{~h}$, as described previously (Benson et al., 2002). Sample processing and analysis was much as described by Benson et al. (2002). Samples were held on ice while being processed and flash frozen using liquid nitrogen immediately after processing. Separate heparinized blood samples $(2 \mathrm{~mL})$ were obtained anaerobically and analyzed for $\mathrm{O}_{2}$ and $\mathrm{CO}_{2}$ content. Plasma from individual samples was analyzed immediately for glucose and p-aminohippurate concentra- tions, and the remainder was composited for each blood vessel and stored frozen until analyzed for lactate and NEFA concentrations. Individual blood samples were deproteinized and the neutralized supernatant stored frozen until analyzed for ammonia and urea concentrations. Blood samples were also composited for each vessel and held on ice until deproteinized; the supernatant obtained was neutralized and centrifuged, and the second supernatant was stored frozen $\left(-20^{\circ} \mathrm{C}\right)$ until analyzed for BHBA concentration. Composites of plasma were stored frozen $\left(-20^{\circ} \mathrm{C}\right)$ until analyzed for individual AA concentrations (Metcalf et al., 1996). Net flux was calculated as venous minus arterial concentration difference times blood flow; thus, positive rates denote net release of a metabolite into venous blood, and negative rates denote net removal from blood supply.

\section{Model Derivation}

A schematic of the PDV tissue bed with respect to AA metabolism is provided in Figure 1. Weekes and Webster (1975) previously examined propionate use by PDV. Although propionate metabolism by the PDV is somewhat different from AA metabolism with respect to sites of absorption, the model used for the aggregated tissue bed would be essentially the same. In that effort, implicit assumptions were that propionate use by PDV tissues was linearly related to the absorption rate and that use from arterial supplies was negligible. With those assumptions, portal appearance can simply be regressed on infusion rate. From the regression, PDV use and GI absorption can be derived (Figure 2a). The assumptions of that study relative to arterial use were valid because large extraction rates by liver and peripheral tissues led to relatively low arterial concentrations and little recycling of absorbed propionate back to the PDV. In the case of AA, hepatic and peripheral extraction is relatively less, and significant quantities of absorbed AA are recycled back to, and used by, the PDV (MacRae et al., 1997a). If such arterial use is not considered in the model, fractional removal by the tissue will be significantly overestimated. This can be demonstrated by simulating a set of data. For this exercise, it was assumed that the PDV use AA from both arterial and absorbed supplies, that the true fractional rate of use by the tissue was 0.15 of total supply, and that the basal absorption rate from the gut lumen was $230 \mu \mathrm{mol} / \mathrm{min}$. Amino acid infusions were then simulated with increments of $0,25,50$, and $75 \mu \mathrm{mol} /$ min. Corresponding arterial fluxes were assumed to be $300,370,440$, and $510 \mu \mathrm{mol} / \mathrm{min}$ (respectively for each level of infusion). As demonstrated in Figure 2a, fitting the model of Weekes and Webster (1975) to the simulated data results in erroneous estimates of fractional use and the basal absorption rate, unless arterial flux is also 

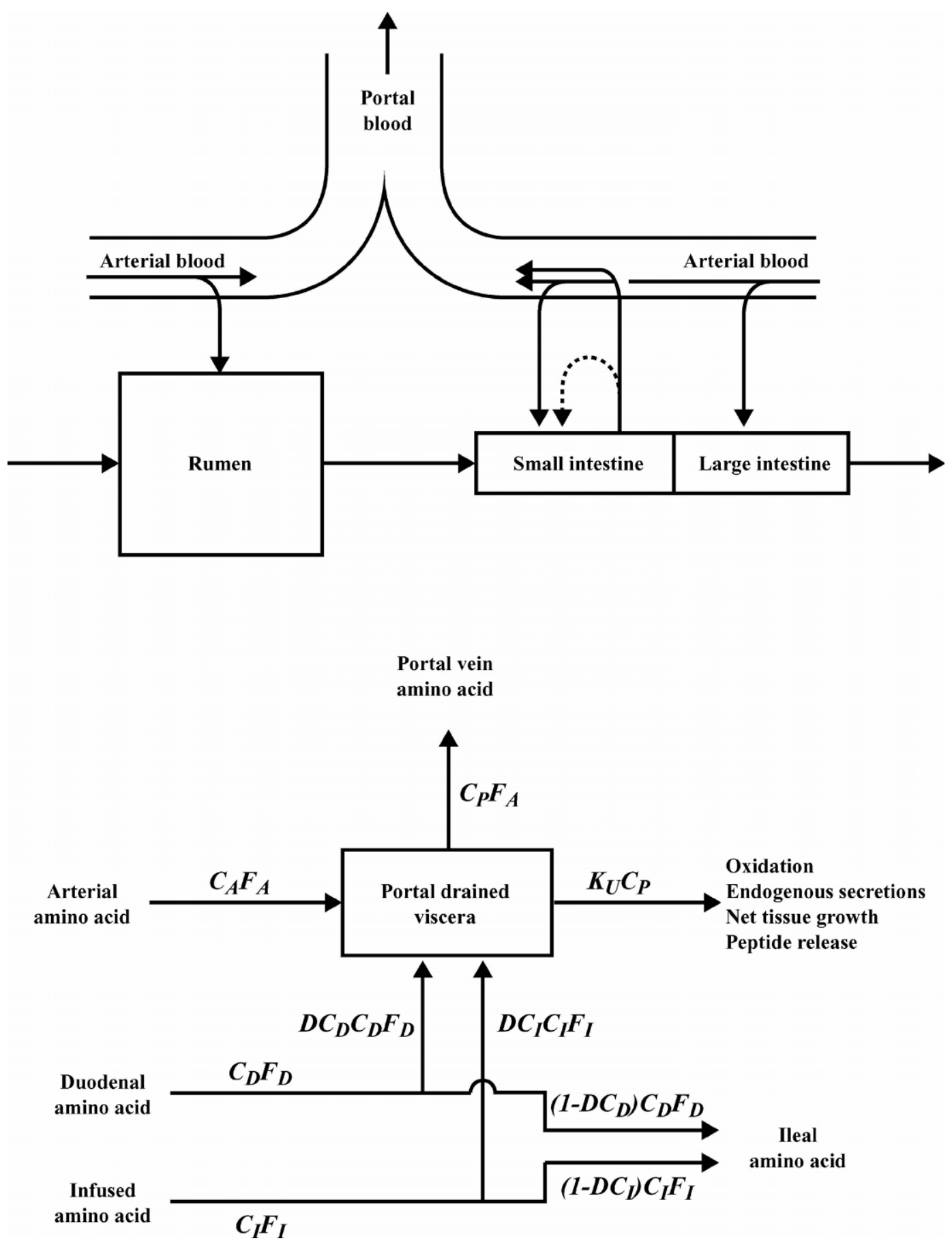

Figure 1. Schematic and flow diagram depicting amino acid fluxes across the portal-drained viscera. Boxes represent pools and arrows represent fluxes. Letters $C, D C, F$, and $K$ represent concentration, digestion coefficient, flow, and rate parameter, respectively. Subscripts $A, D, I$, and $P$ represent arterial, duodenal, infusate, and portal, respectively.

considered in the model. Additionally, the greater arterial concentrations of AA as compared with propionate result in a shallow slope with respect to infusion rates, resulting in the need for relatively large changes in infusion rates to derive a reasonable estimate of basal absorp- tion rates (Figure 2b). Given that inclusion of arterial flux in the model requires consideration of the effects of blood flow, it was determined to derive a new model.

The proposed model as depicted in Figure 1 is a derivation of that described for liver and mammary tissue (Han- 
A
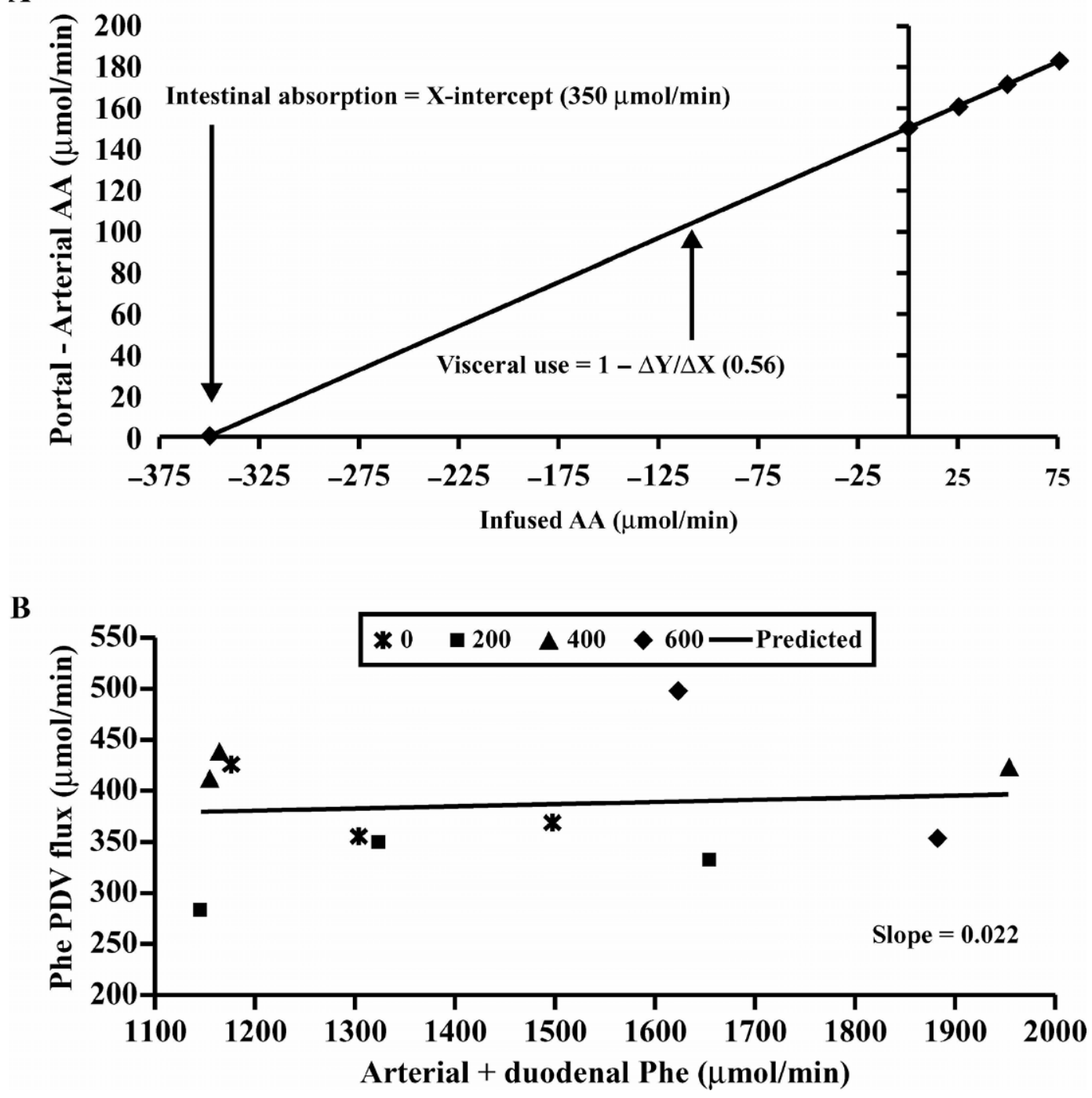

Figure 2. Application of the approach of Weekes and Webster (1975) to derive absorption and portal-drained viscera (PDV) fractional use of a hypothetical AA (A) and Phe observations from this study (B). For the simulated data in A, use by the PDV was presumed to occur from both arterial and absorptive supplies; fractional use was set at 0.15 of supply; absorption from the duodenal supply in the absence of infusion was assumed to be $230 \mu \mathrm{mol} / \mathrm{min}$; infused AA were set at $0,25,50$, and $75 \mu \mathrm{mol} / \mathrm{min}$; and arterial flux was set at 300,370 , 440 , and $510 \mu \mathrm{mol} / \mathrm{min}$ (respectively for each level of infusion). The Weekes and Webster model (1975) was then fitted to the simulated data to derive estimates of fractional use and the basal absorption rate. Failure to consider use of AA from arterial supplies resulted in overestimates of intestinal absorption ( $350 \mathrm{vs.} 230 \mu \mathrm{mol} / \mathrm{min}$ ) and visceral use (0.56 vs. 0.15$)$. In B, both arterial and duodenally absorbed inputs were considered, resulting in an accurate estimate of fractional use by the tissue.

igan et al., 1998b) with modifications to represent luminal AA absorption from dietary and infused protein sources. As discussed by Hanigan et al. (1998b), assumptions required to use this model include 1) extracellular and capillary compartments exchange very rapidly and thus can be considered as one contiguous space, 2) AA concentrations in this contiguous extracellular compartment and intracellular compartments are linearly related, and 3) AA transport into the cell from the interstitial compartment is linearly related to interstitial AA concentrations. Additional assumptions required herein were that use of AA by PDV was not discriminatory with respect to the source, i.e., luminal vs. arterial, and that all protein digested in the lumen was absorbed.

Exchange between capillary and interstitial space has been shown to be rapid and largely occurring via diffusion through pores between endothelial cells (Detweiler, 1984; Risau, 1995). Given that exchange between the compartments is via diffusion, the second assumption would appear to be valid. However, it is likely that ex- 
change is not so rapid as to allow instantaneous equilibration of the 2 compartments. Modeling work has shown that the capillary concentration of small metabolites being extracted by the tissue bed would be expected to decline in an exponential manner as blood traverses the capillary (Cant and McBride, 1995). Interstitial fluid near the beginning of a capillary might then be expected to have metabolite concentrations closer to arterial blood than interstitial fluid near the end of a capillary. However, such interstitial stratification is mitigated by axial diffusion within the interstitial space. The exponential decline in capillary concentration results from a greater concentration gradient between capillary and interstitial space at the beginning of a capillary than at the end, i.e., interstitial and capillary spaces are at or approaching equilibrium by the end of the capillary. Given diffusion within the interstitial space, the propensity for greater interstitial concentrations at the beginning of the capillary is marginalized, and the 2 pools essentially approximate a single instantaneously mixed pool, thus allowing the first assumption to be tenable. A consequence of this system is that metabolite concentrations at the cell surface are not reflective of initial capillary concentrations but rather approximate concentrations at the end of the capillary, which are equivalent to concentrations in venous blood. Thus, metabolite concentrations in interstitial fluid and at the cell surface more closely reflect concentrations in venous blood than arterial.

Certainly absorbed metabolites must enter the interstitial fluid pool before entry into the capillary space. However, AA are believed to be transported into the epithelial cells directly from the gut lumen before being released into the interstitial space (Argenzio, 1993). Thus, there is some opportunity for use of absorbed AA before it is released into the interstitial space. This is a slight deviation from the second assumption. However, the data of MacRae et al. (1997a) suggest that this is a minor deviation. Additionally, if intracellular and interstitial concentrations are related [see further discussion of the model assumptions in Hanigan et al. (1998b)], entry from the luminal side would have a direct affect on interstitial concentrations. Therefore, both arterial and luminal supplies would influence interstitial and venous concentrations, supporting the proposed model.

Given these assumptions, and assuming that the portal vein does not receive significant quantities of blood from sources other than the PDV, extracellular and portal vein concentrations can be assumed to be equivalent, allowing the latter to be calculated in the following manner:

$$
C_{P_{i}}=\frac{C_{A_{i}} F_{A}+D C_{D} C_{D_{i}} F_{D}+D C_{I} C_{I_{i}} F_{I}}{K_{U_{i}}+F_{A}},
$$

where $C_{A}$ and $C_{P}$ represent arterial and portal vein concentrations ( $\mu \mathrm{mol} / \mathrm{L}$ ) of each AA (designated by the subscript i); $C_{D}$ and $C_{I}$ represent duodenal and infusate $\mathrm{AA}$ concentrations [ $\mu \mathrm{mol} / \mathrm{g}$ of nonammonia nitrogen $(\mathbf{N A N})$ ]; $F_{A}, F_{D}$, and $F_{I}$ represent arterial blood (L/min), duodenal $\mathrm{NAN}$, and infusate NAN (g of NAN/min) flows); $D C_{D}$ and $D C_{I}$ represent the true digestion coefficients for ruminally derived and infused NAN (g/g), respectively; and $K_{U}$ represents the rate parameter for net removal of AA (L/min). $K_{U}$ represents the clearance rate of AA at prevailing portal vein concentrations (presumed equivalent to interstitial concentrations); hence the units of $\mathrm{L} / \mathrm{d}$.

As Asn and Gln are destructively reduced to Asp and Glu, respectively, during acid hydrolysis of protein, the content of Asn and Gln in luminal digesta is not normally determined; therefore, Asp and Asn were combined (Asx) for all analyses, as were Glu and Gln $(\mathbf{G l x})$.

Proteins that have been infused into the abomasum include casein, which has an inherently greater digestibility than duodenal NAN derived from dietary sources (Mgheni et al., 1994; Weisbjerg et al., 1996; Mupeta et al., 1997; Rutherfurd and Moughan, 1998; NRC, 2001). Therefore, infused sources were considered separately from NAN derived from ruminal outflow.

Given measurements or knowledge of $C_{A}, C_{P}, C_{D}, F_{A}$, $F_{D}, D C_{D}$, and the infused protein, if any, one can derive $K_{U}$ using a nonlinear fitting routine and equation (1). Alternatively, $K_{U}$ can be calculated directly after rearrangement of equation (1):

$$
K_{U_{i}}=\frac{C_{A_{i}} F_{A}+D C_{D} C_{D_{i}} F_{D}+D C_{I} C_{I_{i}} F_{I}-C_{P_{i}} F_{A}}{C_{P_{i}}}
$$

This latter approach allows derivation of $K_{U}$ for individual animal observations, which can then be subjected to ANOVA to test for treatment differences in tissue activity.

Digestion coefficients in equation (1) represent net true digestion coefficients. Apparent absorption deviates from true absorption due to net loss of AA as endogenous secretions into the digestive tract. Such losses are constrained to the quantity of AA cleared by the PDV per unit of time. Total net clearance by PDV $\left(F_{P D V} ; \mu \mathrm{mol} /\right.$ min) was calculated as:

$$
F_{P D V_{i}}=K_{U_{i}} C_{P_{i}}
$$

Other fates represented in equation (3) include oxidation, export in unmeasured forms such as peptides, and net tissue accretion. Thus, endogenous secretions cannot be greater than $F_{P D V}$.

Although predictions of allowable endogenous protein losses at the ileum were not critical to model derivation, 
Table 3. Amino acid composition of duodenal nonammonia nitrogen (NAN; mmol of AA/g of NAN) reported in the literature.

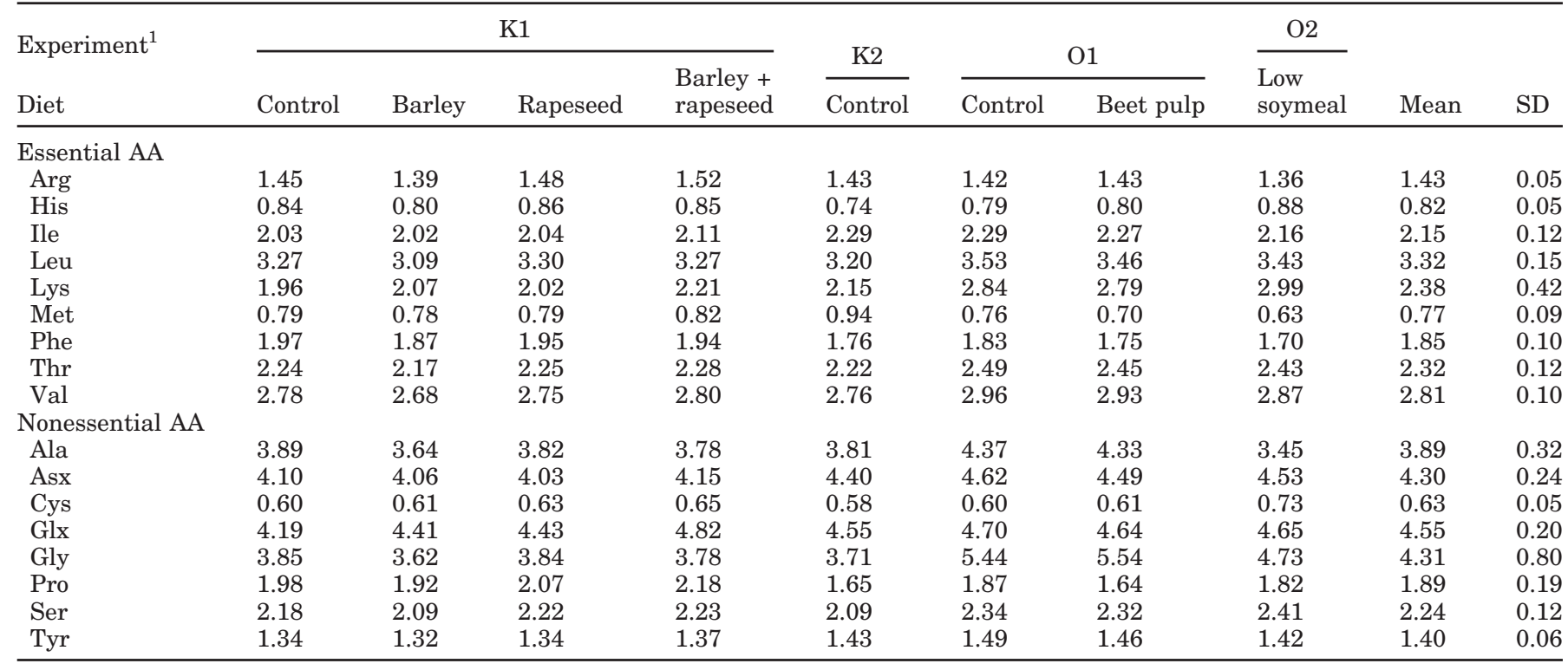

${ }^{1} \mathrm{~K} 1$ = Korhonen et al. (2002a); K2 = Korhonen et al. (2002b); O1 = O’Mara et al. (1997); O2 = O’Mara et al. (1998).

such predictions allow comparison with observations from other experiments and provide additional information regarding reasonable bounds for parameter estimates. The PDV deposits NAN into the lumen of the entire gut in the form of secretions and sloughed cells. Although such losses occur throughout the digestive tract, a significant proportion of the secretions into the rumen and small intestine are reabsorbed. As measurements of ileal net losses have been undertaken, it is useful to separate net losses at the ileum from total losses. If the fractional proportion of PDV essential AA (EAA) use that is lost at the ileum $\left(f_{P D V, E n d}\right)$ is known, then the maximum allowable endogenous losses at the ileum $\left(F_{E n d} ; \mathrm{g} / \mathrm{min}\right)$ can be calculated from $F_{P D V}$ using the endogenous AA composition $\left(f_{E A A, E n d}, \mu \mathrm{mol} / \mathrm{g}\right)$ reported by Storm et al. (1983):

$$
\begin{gathered}
F_{E n d}=\text { Minimum } \\
\left(\frac{F_{P D V_{1}} f_{P D V, E n d}}{f_{E A A_{1}, \text { End }}}, \frac{F_{P D V_{2}} f_{P D V, \text { End }}}{f_{E A A_{2}, \text { End }}}, \ldots, \frac{F_{P D V_{n}} f_{P D V, E n d}}{f_{E A A_{n} \text { End }}}\right)
\end{gathered}
$$

where $f_{P D V, E n d}$ represents the fraction of $F_{P D V}(\mu \mathrm{mol} / \mu \mathrm{mol}$; the subscript $\mathrm{n}$ represents each EAA) appearing at the ileum as endogenous protein. Equation 4 essentially determines the maximum quantity of endogenous protein that could be synthesized from each EAA given its availability and sets the allowable endogenous secretion rate equal to the minimum of the EAA calculated rates. This approach presumes that the first limiting EAA with respect to supply limits the rate of protein synthesis. Hav- ing derived an estimate of allowable endogenous flow, ileal endogenous losses of each AA were calculated as:

$$
F_{E n d A A_{i}}=F_{E n d} f_{A A_{i}, E n d}
$$

Total ileal flow of each AA $\left(F_{I L}, \mu \mathrm{mol} / \mathrm{min}\right)$ was then calculated as the indigestible portions of duodenal and infused proteins plus endogenous losses:

$$
F_{I L_{i}}=\left(1-D C_{D}\right) C_{D_{i}} F_{D}+\left(1-D C_{I}\right) C_{I_{i}} F_{I}+F_{E n d A A_{i}}
$$

Having derived total and endogenous AA flows at the ileum, the fraction of ileal flow $\left(f_{I L, E n d} ; \mu \mathrm{mol} / \mu \mathrm{mol}\right)$ represented by endogenous flow was calculated as:

$$
f_{I L, E n d_{i}}=\frac{F_{E n d A A_{i}}}{F_{I L_{i}}}
$$

\section{Model Fitting}

Because duodenal flows and digestibilities were not measured in this work, estimates of $C_{D}, F_{D}, D C_{D}$, and $D C_{I}$ were required. An attempt was made to derive both $K_{U}$ and the aggregated term $F_{D} \times C_{D} \times D C_{D}$ (the rate of absorption at 0 infusion) in a similar manner as Weekes and Webster (1975), with the exception of considering arterial inputs. However, as demonstrated in Figure 2b, the range of infusion rates was not adequate relative to the measurement error to derive unique estimates for both $K_{U}$ and $F_{D} \times C_{D} \times D C_{D}$. Because $K_{U}$ was the primary parameter of interest, estimates of the basal absorption 
Table 4. Dry matter intake and milk yield and composition during the last $4 \mathrm{~d}$ of $10-\mathrm{d}$ abomasal infusions of casein in 6 dairy cows in late lactation.

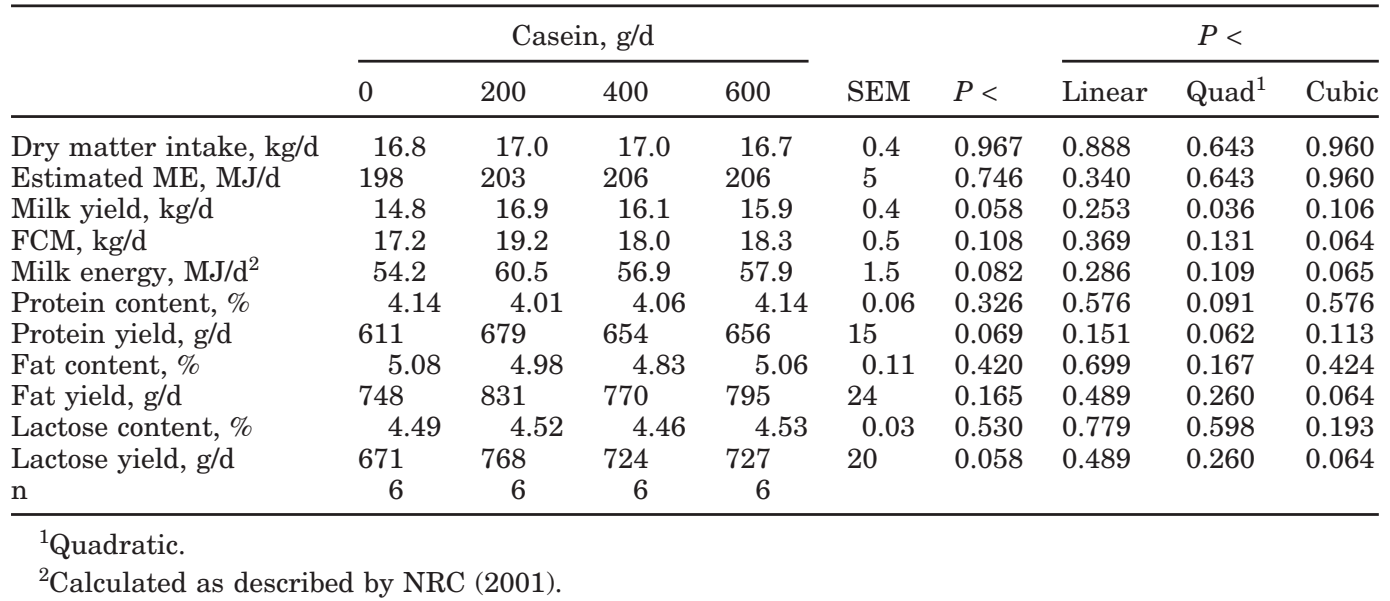

rate were required. Thus $F_{D}$ was assumed to be that predicted from the equation of Clark et al. (1992), and $C_{D}$ was assumed from the observations of Korhonen et al. (2002a; 2002b) and O’Mara et al. (1997; 1998) (Table $3)$. The experiments of Korhonen et al. $(2002 \mathrm{a}, \mathrm{b})$ and O'Mara et al. $(1997,1998)$ were chosen because they used diets that were similar to those fed in the present experiment. $D C_{I}$ was assumed to be 0.95 for all AA, based on the observations of Rutherfurd and Moughan (1998). A range of values for $D C_{D}$ was evaluated as described subsequently. A final assumption was that arterial and portal amino acid concentrations were in steady state.

Using these assumptions, equation (1) was fitted to the experimental data using the DUD method of Proc NLIN in SAS (1990). For fitting, plasma flow and concentrations were used. Having fitted equation (1) to the data, equations (3) to (7) were used to calculate the remaining values for comparison to previous observations.

\section{Statistical Analyses}

Production data analyzed statistically were averages for the last $4 \mathrm{~d}$ of each period $(\mathrm{n}=24)$. In the course of this experiment, problems developed with catheter patency, which resulted in failure to obtain some blood samples. In the end, 17 measurements of arterial metabolite concentration were obtained, but only 11 and 9 measurements of net PDV and liver flux, respectively. The 9 liver flux observations were a subset of the 11 PDV observations, which were a subset of the 17 arterial observations. Therefore, full statistical analysis was conducted only on the production and arterial concentration data. That analysis was performed by ANOVA using the GLM procedures of SAS (1990) and a model testing effects of square, cow within square, period within square, and treatment (casein infusion) using residual error mean squares. In addition, treatment sums of squares were partitioned into linear, quadratic, and cubic effects of casein infusion using orthogonal contrasts. Measurements of net PDV flux were used to derive the mathematical model of AA use by the PDV described subsequently. In addition, net PDV, liver, and total splanchnic flux of metabolites were analyzed for linear, quadratic, and cubic effects of casein infusion without adjustment for animal and period effects using the GLM procedure of SAS (1990) as described previously, and those data are presented in tabular form. As the number of observations was limited, differences are presented as significant at $P<0.10$. However, the emphasis of the present paper will be the development of a mathematical model of AA use by the PDV.

\section{RESULTS}

\section{Experimental}

Abomasal casein infusion had no effect on feed DMI (which excludes infused casein DM) or total ME intake (estimated using tabular values and including casein infused), but increased milk yield in a quadratic manner $(P<0.04)$ such that the greatest increase occurred at the lowest level of infusion (Table 4). Milk protein yield also increased (quadratic, $P<0.07$ ), and milk protein concentration was reduced at the lower levels of infusion (quadratic, $P<0.10$ ). Estimated milk energy and fatcorrected milk yields tended to increase slightly (cubic, $P<0.07)$, but calculated tissue energy balance $(60 \mathrm{MJ} /$ d) was not affected in these late-lactation cows. Arterial concentrations of a number of EAA were increased linearly by abomasal casein infusion (Table 5; Val, $P<0.01$; Leu, $P<0.01$; Ile, $P<0.01$; Met, $P<0.09$; Phe, $P<0.03$; total EAA, $P<0.002$ ), whereas arterial Thr concentration 
Table 5. Effect of incremental abomasal infusion of casein on arterial concentrations $(\mu \mathrm{mol} / \mathrm{L})$ of amino acids.

\begin{tabular}{|c|c|c|c|c|c|c|c|c|c|}
\hline & \multicolumn{4}{|c|}{ Casein infusion, $\mathrm{g} / \mathrm{d}$} & \multirow[b]{2}{*}{ SEM } & \multirow[b]{2}{*}{$P<$} & \multicolumn{3}{|c|}{$P<$} \\
\hline & 0 & 200 & 400 & 600 & & & Linear & Quad $^{1}$ & Cubic \\
\hline Valine & 258.1 & 291.5 & 324.5 & 380.7 & 8.2 & 0.001 & 0.001 & 0.270 & 0.533 \\
\hline Leucine & 148.2 & 162.4 & 188.7 & 221.6 & 4.2 & 0.001 & 0.001 & 0.102 & 0.775 \\
\hline Isoleucine & 134.9 & 139.8 & 157.0 & 169.9 & 4.2 & 0.004 & 0.001 & 0.438 & 0.400 \\
\hline Total branched-chain AA & 541.2 & 593.8 & 670.2 & 772.2 & 15.7 & 0.001 & 0.001 & 0.220 & 0.982 \\
\hline Methionine & 15.1 & 17.2 & 19.9 & 17.6 & 1.2 & 0.126 & 0.085 & 0.144 & 0.308 \\
\hline Lysine & 100.8 & 103.8 & 128.0 & 121.8 & 12.3 & 0.317 & 0.146 & 0.752 & 0.377 \\
\hline Threonine & 91.4 & 87.5 & 108.6 & 92.4 & 5.2 & 0.107 & 0.312 & 0.338 & 0.038 \\
\hline Phenylalanine & 46.4 & 46.6 & 48.4 & 53.2 & 1.8 & 0.106 & 0.028 & 0.293 & 0.850 \\
\hline Tryptophan & 36.5 & 40.1 & 43.4 & 36.0 & 3.2 & 0.534 & 0.893 & 0.188 & 0.485 \\
\hline Histidine & 42.7 & 46.2 & 51.7 & 49.2 & 4.0 & 0.433 & 0.194 & 0.541 & 0.592 \\
\hline Total essential AA & 874.1 & 935.2 & 1070.1 & 1142.4 & 36.8 & 0.008 & 0.002 & 0.898 & 0.429 \\
\hline Arginine & 98.7 & 86.3 & 98.9 & 87.2 & 7.2 & 0.412 & 0.495 & 0.971 & 0.172 \\
\hline Ornithine & 68.0 & 67.5 & 80.1 & 81.0 & 7.3 & 0.351 & 0.149 & 0.938 & 0.475 \\
\hline Citrulline & 69.9 & 78.9 & 88.5 & 86.6 & 7.1 & 0.270 & 0.096 & 0.523 & 0.705 \\
\hline Total urea cycle AA & 236.5 & 232.7 & 267.5 & 254.8 & 15.5 & 0.330 & 0.219 & 0.808 & 0.253 \\
\hline Alanine & 200.1 & 192.2 & 214.8 & 192.8 & 7.4 & 0.247 & 0.978 & 0.437 & 0.066 \\
\hline Glycine & 195.7 & 176.8 & 182.8 & 171.8 & 12.5 & 0.521 & 0.258 & 0.788 & 0.473 \\
\hline Serine & 76.6 & 73.5 & 78.5 & 85.1 & 4.7 & 0.376 & 0.180 & 0.402 & 0.763 \\
\hline Aspartate & 17.0 & 17.0 & 18.0 & 17.2 & 1.2 & 0.893 & 0.735 & 0.753 & 0.570 \\
\hline Asparagine & 28.6 & 28.0 & 33.8 & 28.6 & 2.7 & 0.498 & 0.648 & 0.492 & 0.202 \\
\hline Glutamate & 77.7 & 75.9 & 69.8 & 72.7 & 1.9 & 0.085 & 0.044 & 0.325 & 0.163 \\
\hline Glutamine & 167.0 & 161.7 & 171.0 & 170.6 & 10.7 & 0.859 & 0.569 & 0.849 & 0.626 \\
\hline Proline & 66.9 & 76.7 & 103.6 & 103.0 & 9.2 & 0.053 & 0.017 & 0.638 & 0.311 \\
\hline Tyrosine & 50.6 & 50.0 & 58.0 & 62.7 & 4.0 & 0.128 & 0.043 & 0.576 & 0.516 \\
\hline Total nonessential AA & 1131.1 & 1098.9 & 1212.2 & 1173.7 & 59.1 & 0.482 & 0.375 & 0.965 & 0.303 \\
\hline Total & 1995.8 & 2024.7 & 2272.9 & 2306.8 & 92.0 & 0.085 & 0.028 & 0.983 & 0.332 \\
\hline $\mathrm{n}$ & 4 & 5 & 4 & 4 & & & & & \\
\hline
\end{tabular}

${ }^{1}$ Quadratic effect of casein infusion.

increased in a cubic manner $(P<0.04)$. The response of nonessential AA concentration was more variable. Arterial concentration of Cit $(P<0.10)$, Pro $(P<0.02)$, and Tyr $(P<0.05)$ increased linearly, whereas arterial concentration of Glu decreased (linear, $P<0.05$ ), and arterial concentration of Ala varied in a cubic fashion $(P<0.07)$. Total nonessential AA concentration in arterial plasma was not affected by casein infusion, but total AA concentration was increased linearly $(P<0.03)$, mainly due to the large increases in branched-chain AA (BCAA) concentration observed.

Abomasal infusion of casein also caused a linear increase $(P<0.002)$ in arterial urea concentration (Table $6)$, whereas arterial concentration of BHBA $(P<0.06)$

Table 6. Effect of incremental abomasal casein infusion on arterial concentrations of metabolites (mmol/ L) in lactating dairy cows.

\begin{tabular}{|c|c|c|c|c|c|c|c|c|c|}
\hline & \multicolumn{4}{|c|}{ Casein infusion, g/d } & \multirow[b]{2}{*}{ SEM } & \multirow[b]{2}{*}{$P<$} & \multicolumn{3}{|c|}{$P<$} \\
\hline & 0 & 200 & 400 & 600 & & & Linear & Quad $^{1}$ & Cubic \\
\hline \multirow{2}{*}{\multicolumn{10}{|c|}{ Arterial concentration, $\mathrm{mmol} / \mathrm{L}$}} \\
\hline & & & & & & & & & Blood \\
\hline Ammonia & 0.100 & 0.141 & 0.133 & 0.139 & 0.021 & 0.420 & 0.265 & 0.495 & 0.508 \\
\hline Urea & 2.87 & 3.73 & 4.58 & 4.65 & 0.25 & 0.008 & 0.002 & 0.219 & 0.501 \\
\hline Oxygen & 4.75 & 4.82 & 5.11 & 4.72 & 0.28 & 0.824 & 0.864 & 0.486 & 0.490 \\
\hline Carbon dioxide & 27.73 & 28.26 & 27.11 & 27.29 & 0.40 & 0.176 & 0.196 & 0.718 & 0.145 \\
\hline BHBA & 0.889 & 0.842 & 0.977 & 0.779 & 0.049 & 0.217 & 0.381 & 0.232 & 0.060 \\
\hline \multicolumn{10}{|l|}{ Plasma } \\
\hline Glucose & 3.66 & 3.60 & 3.75 & 3.64 & 0.17 & 0.918 & 0.894 & 0.913 & 0.555 \\
\hline L-Lactate & 0.258 & 0.292 & 0.258 & 0.257 & 0.028 & 0.622 & 0.763 & 0.602 & 0.433 \\
\hline NEFA & 0.093 & 0.105 & 0.119 & 0.070 & 0.008 & 0.090 & 0.173 & 0.025 & 0.129 \\
\hline $\begin{array}{l}\text { Arterial PCV, } \\
\mathrm{n}\end{array}$ & $\begin{array}{c}23.8 \\
4\end{array}$ & $\begin{array}{c}25.8 \\
5\end{array}$ & $\begin{array}{c}25.6 \\
4\end{array}$ & $\begin{array}{c}24.7 \\
4\end{array}$ & 1.2 & 0.487 & 0.613 & 0.196 & 0.772 \\
\hline
\end{tabular}


Table 7. Effect of incremental abomasal infusion of casein on blood flow (L/min) for the portal vein and liver of lactating cows.

\begin{tabular}{|c|c|c|c|c|c|c|c|c|c|}
\hline & \multicolumn{4}{|c|}{ Casein, g/d } & \multirow[b]{2}{*}{ SEM } & \multirow[b]{2}{*}{$P<$} & \multicolumn{3}{|c|}{$P<$} \\
\hline & 0 & 200 & 400 & 600 & & & Linear & Quad $^{1}$ & Cubic \\
\hline \multicolumn{10}{|c|}{ Portal vein } \\
\hline Plasma & 19.3 & 20.0 & 18.1 & 22.2 & 3.1 & 0.781 & 0.605 & 0.545 & 0.476 \\
\hline Blood & 25.3 & 26.9 & 24.5 & 29.4 & 4.4 & 0.833 & 0.592 & 0.673 & 0.509 \\
\hline $\mathrm{n}$ & 3 & 3 & 3 & 2 & & & & & \\
\hline \multicolumn{10}{|l|}{ Liver } \\
\hline Plasma & 21.2 & 23.6 & 22.5 & 28.1 & 2.4 & 0.316 & 0.132 & 0.532 & 0.360 \\
\hline Blood & 28.1 & 31.9 & 30.3 & 37.2 & 3.5 & 0.386 & 0.159 & 0.671 & 0.382 \\
\hline $\mathrm{n}$ & 2 & 2 & 3 & 2 & & & & & \\
\hline
\end{tabular}

${ }^{1}$ Quadratic effect of casein infusion.

varied in a cubic manner, being highest at $400 \mathrm{~g}$ of casein/ $\mathrm{d}$ and lowest at the highest level of casein infusion. Arterial concentration of NEFA was also affected (quadratic, $P<0.03)$, and was highest when $400 \mathrm{~g}$ of casein was infused daily. There were no other effects $(P>0.10)$ of casein infusion on arterial concentrations of the metabolites measured.

Casein infusion had no effect $(P>0.10)$ on blood or plasma flow in the portal vein or liver (Table 7), and variable effects on net PDV (Table 8), and liver (Table 9) flux of AA. Casein infusion linearly increased both net portal appearance [also denoted as PDV release (Table 8)] and liver removal (Table 9) of Met $(P<0.005$ and $P$ $<0.05$, respectively) and Ala $(P<0.02$ and $P<0.07$, respectively), and net PDV release of $\operatorname{Asp}(P<0.10)$ and Gln $(P<0.01)$. In addition, there were cubic effects on net PDV release of $\mathrm{Val}(P<0.08)$, total BCAA $(P<0.10)$, total EAA $(P<0.08)$, Arg $(P<0.005)$, Asn $(P<0.003)$, Tyr $(P<0.02)$, total nonessential AA $(P<0.002)$, and total AA $(P<0.004)$. These changes largely reflected a pattern of changes in which net PDV release was decreased by the lowest level of casein infusion and was

Table 8. Effect of incremental abomasal infusion of casein on net portal-drained visceral flux (portal arterial flux, $\mu \mathrm{mol} / \mathrm{min}$ ) of amino acids.

\begin{tabular}{|c|c|c|c|c|c|c|c|c|c|}
\hline & \multicolumn{4}{|c|}{ Casein infusion, g/d } & \multirow[b]{2}{*}{ SEM } & \multirow[b]{2}{*}{$P<$} & \multicolumn{3}{|c|}{$P<$} \\
\hline & 0 & 200 & 400 & 600 & & & Linear & Quad $^{1}$ & Cubic \\
\hline Valine & 602 & 343 & 644 & 450 & 135 & 0.287 & 0.783 & 0.788 & 0.073 \\
\hline Leucine & 689 & 471 & 714 & 651 & 118 & 0.350 & 0.798 & 0.475 & 0.122 \\
\hline Isoleucine & 523 & 337 & 503 & 402 & 104 & 0.432 & 0.656 & 0.650 & 0.150 \\
\hline Total branched-chain AA & 1815 & 1151 & 1861 & 1503 & 346 & 0.336 & 0.877 & 0.626 & 0.098 \\
\hline Methionine & 161 & 141 & 212 & 223 & 16 & 0.011 & 0.005 & 0.299 & 0.036 \\
\hline Lysine & 775 & 553 & 670 & 648 & 135 & 0.592 & 0.641 & 0.423 & 0.370 \\
\hline Threonine & 442 & 302 & 473 & 456 & 58 & 0.130 & 0.396 & 0.259 & 0.054 \\
\hline Phenylalanine & 383 & 320 & 424 & 427 & 34 & 0.108 & 0.133 & 0.300 & 0.072 \\
\hline Tryptophan & 90 & -12 & 51 & 87 & 27 & 0.047 & 0.642 & 0.020 & 0.090 \\
\hline Histidine & 162 & 108 & 153 & 172 & 28 & 0.328 & 0.519 & 0.183 & 0.271 \\
\hline Total essential AA & 3829 & 2564 & 3845 & 3516 & 531 & 0.214 & 0.878 & 0.343 & 0.072 \\
\hline Arginine & 393 & 169 & 439 & 416 & 53 & 0.012 & 0.159 & 0.067 & 0.005 \\
\hline Ornithine & 215 & 108 & 135 & 63 & 52 & 0.213 & 0.082 & 0.718 & 0.265 \\
\hline Citrulline & 192 & 188 & 182 & 115 & 66 & 0.803 & 0.407 & 0.594 & 0.815 \\
\hline Total urea cycle AA & 799 & 465 & 757 & 593 & 134 & 0.213 & 0.568 & 0.488 & 0.066 \\
\hline Alanine & 1169 & 973 & 1401 & 1484 & 111 & 0.026 & 0.018 & 0.188 & 0.050 \\
\hline Glycine & 628 & 497 & 724 & 426 & 104 & 0.186 & 0.397 & 0.382 & 0.055 \\
\hline Serine & 625 & 515 & 706 & 726 & 60 & 0.079 & 0.080 & 0.251 & 0.071 \\
\hline Aspartate & 96 & 68 & 97 & 148 & 24 & 0.172 & 0.097 & 0.100 & 0.712 \\
\hline Asparagine & 378 & 319 & 420 & 291 & 31 & 0.018 & 0.193 & 0.157 & 0.003 \\
\hline Glutamate & 157 & 48 & 92 & -19 & 94 & 0.545 & 0.242 & 0.989 & 0.405 \\
\hline Glutamine & 318 & 265 & 532 & 589 & 77 & 0.028 & 0.010 & 0.436 & 0.103 \\
\hline Proline & 303 & 272 & 445 & 394 & 70 & 0.218 & 0.158 & 0.872 & 0.143 \\
\hline Tyrosine & 338 & 269 & 388 & 368 & 28 & 0.035 & 0.105 & 0.347 & 0.015 \\
\hline Total nonessential AA & 4810 & 3691 & 5562 & 4053 & 471 & 0.014 & 0.819 & 0.580 & 0.002 \\
\hline Total & 8639 & 6255 & 9407 & 6595 & 958 & 0.025 & 0.415 & 0.763 & 0.004 \\
\hline $\mathrm{n}$ & 3 & 3 & 3 & 2 & & & & & \\
\hline
\end{tabular}

${ }^{1}$ Quadratic effect of casein infusion. 
Table 9. Effect of incremental abomasal infusion of casein on net liver flux (venous - arterial - portal flux, $\mu \mathrm{mol} / \mathrm{min}$ ) of amino acids.

\begin{tabular}{|c|c|c|c|c|c|c|c|c|c|}
\hline & \multicolumn{4}{|c|}{ Casein infusion, $\mathrm{g} / \mathrm{d}$} & \multirow[b]{2}{*}{ SEM } & \multirow[b]{2}{*}{$P<$} & \multicolumn{3}{|c|}{$P<$} \\
\hline & 0 & 200 & 400 & 600 & & & Linear & Quad $^{1}$ & Cubic \\
\hline Valine & 0 & 223 & 43 & 113 & 184 & 0.830 & 0.856 & 0.683 & 0.428 \\
\hline Leucine & -89 & 19 & 56 & 2 & 170 & 0.926 & 0.698 & 0.640 & 0.978 \\
\hline Isoleucine & -58 & 139 & 77 & 83 & 94 & 0.549 & 0.425 & 0.339 & 0.442 \\
\hline Total branched-chain AA & -146 & 380 & 176 & 198 & 428 & 0.850 & 0.681 & 0.565 & 0.611 \\
\hline Methionine & -76 & -107 & -124 & -192 & 29 & 0.153 & 0.039 & 0.536 & 0.621 \\
\hline Lysine & -446 & -227 & -205 & -371 & 171 & 0.689 & 0.758 & 0.292 & 0.987 \\
\hline Threonine & -208 & -127 & -182 & -291 & 80 & 0.574 & 0.432 & 0.270 & 0.812 \\
\hline Phenylalanine & -244 & -247 & -281 & -398 & 62 & 0.355 & 0.132 & 0.382 & 0.851 \\
\hline Tryptophan & -26 & 52 & -15 & -119 & 49 & 0.227 & 0.175 & 0.112 & 0.616 \\
\hline Histidine & -89 & -28 & -71 & -183 & 31 & 0.070 & 0.065 & 0.034 & 0.790 \\
\hline Total essential AA & -1236 & -302 & -702 & -1355 & 673 & 0.675 & 0.810 & 0.273 & 0.713 \\
\hline Arginine & -252 & -131 & -275 & -450 & 141 & 0.515 & 0.292 & 0.322 & 0.701 \\
\hline Ornithine & 26 & 191 & 119 & 170 & 78 & 0.511 & 0.346 & 0.481 & 0.318 \\
\hline Citrulline & -65 & 80 & 2 & 21 & 31 & 0.096 & 0.245 & 0.086 & 0.055 \\
\hline Total urea cycle AA & -292 & 140 & -153 & -259 & 188 & 0.433 & 0.825 & 0.196 & 0.292 \\
\hline Alanine & -1067 & -857 & -1412 & -1763 & 264 & 0.194 & 0.074 & 0.317 & 0.414 \\
\hline Glycine & -749 & -501 & -805 & -900 & 186 & 0.520 & 0.401 & 0.379 & 0.367 \\
\hline Serine & -594 & -591 & -677 & -892 & 111 & 0.295 & 0.103 & 0.352 & 0.933 \\
\hline Aspartate & -34 & -1 & 9 & -66 & 33 & 0.393 & 0.582 & 0.147 & 0.653 \\
\hline Asparagine & -232 & -259 & -284 & -272 & 44 & 0.835 & 0.570 & 0.706 & 0.873 \\
\hline Glutamate & 716 & 810 & 594 & 873 & 83 & 0.160 & 0.522 & 0.297 & 0.065 \\
\hline Glutamine & -526 & -620 & -674 & -1201 & 216 & 0.234 & 0.082 & 0.344 & 0.590 \\
\hline Proline & -141 & -137 & -190 & -327 & 117 & 0.655 & 0.292 & 0.556 & 0.957 \\
\hline Tyrosine & -217 & -212 & -262 & -376 & 72 & 0.427 & 0.162 & 0.428 & 0.974 \\
\hline Total nonessential AA & -3135 & -2229 & -3853 & -4184 & 985 & 0.602 & 0.417 & 0.592 & 0.412 \\
\hline Total & -4371 & -2530 & -4555 & -4960 & 1469 & 0.704 & 0.655 & 0.518 & 0.428 \\
\hline $\mathrm{n}$ & 2 & 2 & 3 & 2 & & & & & \\
\hline
\end{tabular}

${ }^{1}$ Quadratic effect of casein infusion.

greatest with the intermediate level of infusion ( $400 \mathrm{~g} /$ d). In addition, net PDV release of Trp was reduced (quadratic, $P<0.02$ ) when casein was infused. Net liver removal of His was reduced at the lowest level of casein infusion, and increased by the highest level of infusion (quadratic, $P<0.04$ ). Net liver flux of Cit was negative when water was infused and switched to net release when casein was infused (cubic, $P<0.06$ ), whereas net liver removal of Gln was increased (linear, $P<0.09$ ) by casein infusion. Casein infusion had no effect on net PDV (Table 10) or liver (Table 11) flux of the other metabolites measured, except for an increase in net liver release of BHBA (quadratic, $P<0.10$ ) at the 2 lower levels of casein infusion.

\section{Modeling}

Initial efforts to derive model parameters included an evaluation of the assumption regarding $D C_{D}$. To assess the impact of that assumption, the model was fit to the data while varying $D C_{D}$ from 0.65 to 0.95 . Results are presented in Table 12. As $D C_{D}$ was increased from 0.65 , the error sum of squares across AA generally increased, although the root mean square prediction error for portal concentrations did not increase for all AA, i.e., Lys and the BCAA. Based on the rate parameter estimates for
Lys, it would seem that all solutions where $D C_{D}$ was 0.75 or less were invalid, as those suggest sustained synthesis of Lys (and other EAA at lesser values for $D C_{D}$ ) by the PDV tissues $\left(K_{U}<0\right)$, which is not possible. The results also demonstrated that $K_{U}$ estimates were sensitive to the assumed value for $D C_{D}$, and thus this is an important measurement. Because a value of 0.8 for $D C_{D}$ was consistent with previous observations (NRC, 2001) and provided for at least minimal use of Lys by the PDV, a value of 0.8 was adopted for further analyses. Residual errors associated with model fits using this assumption are presented in Figures 3 and 4.

Having assessed the impact of assumptions regarding $D C_{D}$, the total potential net loss of protein into the gut as endogenous secretions was found to be $18.4 \mathrm{~g}$ of N/d if lysine was not considered in the calculation (Table 13; the lysine assumption is discussed subsequently). This value is slightly less than the $25 \mathrm{~g}$ of $\mathrm{N} / \mathrm{d}$ observed by Ouellet et al. (2002). Based on previous observations in sheep (Sandek et al., 2001), net losses at the ileum can represent a variable proportion of those in feces. However, from gut mass (Gibb et al., 1992), one would expect the endogenous loss at the ileum to represent approximately $60 \%$ of net total PDV loss. As such, a value of 0.6 for $f_{E A A, E n d}$ was adopted for further work and for comparisons to studies where ileal losses were measured. 
Table 10. Effect of incremental abomasal casein infusion on net portal-drained visceral flux (portal - arterial flux, $\mathrm{mmol} / \mathrm{min}$ ) of metabolites in lactating dairy cows.

\begin{tabular}{|c|c|c|c|c|c|c|c|c|c|}
\hline & \multicolumn{4}{|c|}{ Casein infusion, $\mathrm{g} / \mathrm{d}$} & \multirow[b]{2}{*}{ SEM } & \multirow[b]{2}{*}{$P<$} & \multicolumn{3}{|c|}{$P<$} \\
\hline & 0 & 200 & 400 & 600 & & & Linear & Quad $^{1}$ & Cubic \\
\hline \multicolumn{10}{|l|}{ Blood } \\
\hline Urea & -1.87 & -4.88 & -2.60 & -5.65 & 2.17 & 0.487 & 0.333 & 0.996 & 0.227 \\
\hline Ammonia & 6.47 & 10.0 & 7.80 & 8.88 & 1.63 & 0.358 & 0.469 & 0.415 & 0.178 \\
\hline Oxygen & -36.8 & -34.5 & -30.0 & -48.5 & 6.38 & 0.243 & 0.273 & 0.101 & 0.322 \\
\hline Carbon dioxide & 14.6 & 20.4 & 23.7 & 21.5 & 11.5 & 0.915 & 0.624 & 0.698 & 0.947 \\
\hline BHBA & 2.67 & 2.85 & 2.05 & 3.17 & 0.70 & 0.634 & 0.808 & 0.465 & 0.293 \\
\hline \multicolumn{10}{|l|}{ Plasma } \\
\hline Glucose & 0.48 & -0.08 & 0.17 & -0.38 & 0.57 & 0.668 & 0.335 & 0.975 & 0.460 \\
\hline L-Lactate & 1.17 & 1.03 & 0.98 & 1.23 & 0.25 & 0.836 & 0.854 & 0.396 & 0.829 \\
\hline NEFA & 0.53 & 0.32 & 0.30 & 0.55 & 0.22 & 0.657 & 0.968 & 0.238 & 0.962 \\
\hline $\mathrm{n}$ & 3 & 3 & 3 & 2 & & & & & \\
\hline
\end{tabular}

${ }^{1}$ Quadratic effect of casein infusion.

Mean arterial, portal vein, and duodenal fluxes, estimated PDV usage, and estimates of $K_{U}$ are reported in Table $14 . K_{U}$ was significantly different from zero for all AA except Arg, Lys, and Ser. As the units for $K_{U}$ were $\mathrm{L} / \mathrm{min}$ for all AA evaluated, relative affinities can be compared across AA. Portal-drained viscera affinities for the nonessential AA Asx, Glx, Gly, and Pro were relatively great, whereas affinities for Arg, Ile, Lys, Ser, Tyr, and Val were much less. Alanine was released from PDV on a net basis. Using the overall mean plasma flow of 19.65 L/min, Asx clearance of $9.05 \mathrm{~L} / \mathrm{min}$ represents a fractional extraction of $32 \%(9.05 /[19.65+9.05] \times 100)$. Fractional extraction of Met was $5.6 \%$ and Lys was $0.5 \%$.

Root mean square prediction errors for portal AA concentrations were in the 5 to $7 \%$ range (Table 14), offering no suggestion that the model was inappropriate. However, portal concentrations were significantly influenced by arterial concentrations, necessitating some caution in interpretation of those values. Another measure of model identifiability and validity is provided by comparison of the standard error of parameter estimates with the esti- mated parameters, i.e., $K_{U}$. Standard errors that are greater than $50 \%$ of the estimates generally indicate an identity problem with the model, an inappropriate model, or inadequate data. Excepting those estimates near zero, all SE were much less than $50 \%$ of the parameter estimates (Table 14).

\section{DISCUSSION}

\section{Amino Acid Concentrations and Splanchnic Clearance}

Arterial concentrations of numerous EAA increased linearly in response to incremental casein infusion, indicating that the total arterial pool and postabsorptive EAA supply increased linearly. Linear increases in arterial EAA suggest that tissue removal of the added EAA was via mass action and that no changes in tissue affinity or capacity occurred on a whole-body basis. Hepatic clearance of AA in response to changes in arterial and portal AA concentrations previously have been demonstrated

Table 11. Effect of incremental abomasal casein infusion on net liver flux (venous - arterial - portal flux, $\mathrm{mmol} / \mathrm{min}$ ) of metabolites in lactating dairy cows.

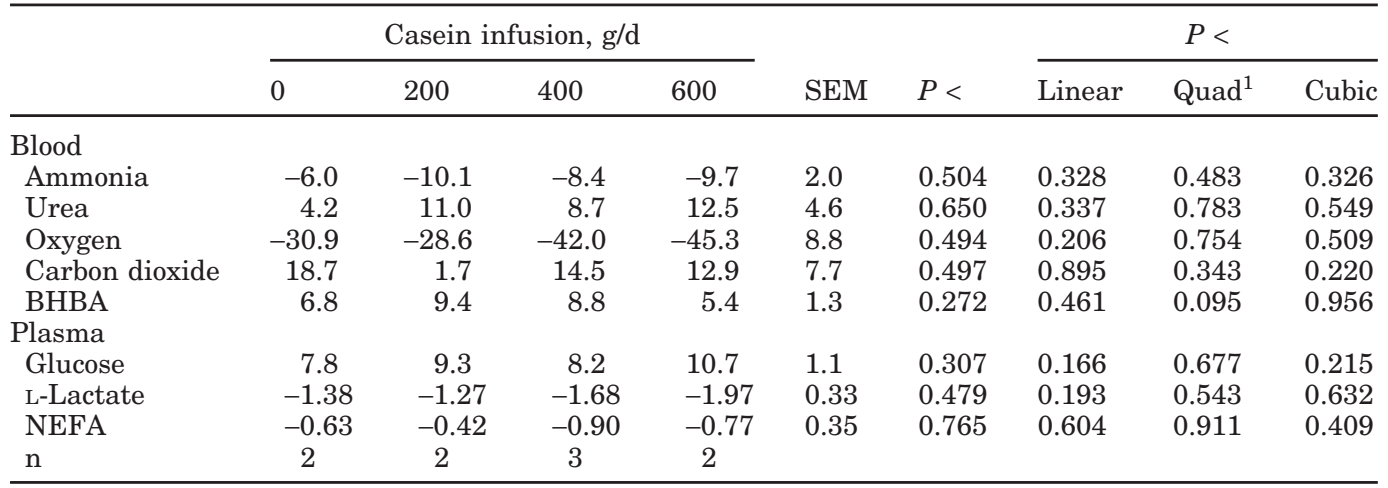

\footnotetext{
${ }^{1}$ Quadratic effect of casein infusion.
} 
Table 12. Sensitivity of $K_{U}(\mathrm{~L} / \mathrm{min})$ and errors of portal concentration predictions (RMSE; $\mu \mathrm{mol} / \mathrm{L}$ ) to variations in $D C_{D}$.

\begin{tabular}{|c|c|c|c|c|c|c|c|c|c|c|c|c|c|c|}
\hline \multirow[b]{2}{*}{$D C_{D}$} & \multicolumn{2}{|c|}{0.65} & \multicolumn{2}{|c|}{0.7} & \multicolumn{2}{|c|}{0.75} & \multicolumn{2}{|c|}{0.8} & \multicolumn{2}{|c|}{0.85} & \multicolumn{2}{|c|}{0.9} & \multicolumn{2}{|c|}{0.95} \\
\hline & $K_{U}$ & $\mathrm{RMSE}^{1}$ & $K_{U}$ & RMSE & $K_{U}$ & RMSE & $K_{U}$ & RMSE & $K_{U}$ & RMSE & $K_{U}$ & RMSE & $K_{U}$ & RMSE \\
\hline \multicolumn{15}{|c|}{ Essential AA } \\
\hline Arg & -0.34 & 7.1 & -0.16 & 7.1 & 0.02 & 7.2 & 0.19 & 7.2 & 0.37 & 7.2 & 0.55 & 7.2 & 0.73 & 7.2 \\
\hline His & 0.76 & 2.7 & 0.97 & 2.8 & 1.18 & 2.8 & 1.39 & 2.9 & 1.60 & 3.0 & 1.81 & 3.0 & 2.02 & 3.1 \\
\hline Ile & 0.16 & 9.0 & 0.34 & 9.0 & 0.53 & 8.9 & 0.71 & 8.9 & 0.90 & 8.9 & 1.08 & 8.9 & 1.27 & 8.9 \\
\hline Leu & 0.60 & 10.0 & 0.84 & 9.9 & 1.08 & 9.9 & 1.32 & 9.8 & 1.56 & 9.8 & 1.80 & 9.8 & 2.05 & 9.9 \\
\hline Lys & -0.59 & 11.1 & -0.36 & 11.1 & -0.13 & 11.0 & 0.10 & 10.9 & 0.33 & 10.9 & 0.57 & 10.9 & 0.80 & 10.8 \\
\hline Met & -0.08 & 1.4 & 0.34 & 1.5 & 0.76 & 1.5 & 1.17 & 1.6 & 1.59 & 1.6 & 2.01 & 1.7 & 2.44 & 1.7 \\
\hline Phe & 0.29 & 3.2 & 0.69 & 3.2 & 1.09 & 3.2 & 1.49 & 3.3 & 1.90 & 3.3 & 2.30 & 3.3 & 2.70 & 3.3 \\
\hline Thr & 0.63 & 6.2 & 0.93 & 6.5 & 1.23 & 6.7 & 1.54 & 6.9 & 1.84 & 7.1 & 2.14 & 7.3 & 2.45 & 7.5 \\
\hline Val & 0.36 & 11.7 & 0.49 & 11.7 & 0.61 & 11.7 & 0.74 & 11.6 & 0.87 & 11.6 & 1.00 & 11.6 & 1.13 & 11.7 \\
\hline \multicolumn{15}{|c|}{ Nonessential AA } \\
\hline Ala & -1.50 & 11.4 & -1.29 & 11.2 & -1.08 & 11.0 & -0.86 & 10.9 & -0.65 & 10.9 & -0.44 & 10.8 & -0.23 & 10.8 \\
\hline Asx & 6.33 & 5.8 & 7.23 & 6.0 & 8.14 & 6.1 & 9.05 & 6.3 & 9.95 & 6.4 & 10.86 & 6.6 & 11.77 & 6.7 \\
\hline Glx & 2.40 & 10.9 & 2.66 & 11.0 & 2.92 & 11.2 & 3.17 & 11.3 & 3.43 & 11.4 & 3.69 & 11.6 & 3.94 & 11.7 \\
\hline Gly & 1.25 & 10.2 & 1.54 & 10.6 & 1.84 & 11.0 & 2.13 & 11.4 & 2.43 & 11.8 & 2.72 & 12.3 & 3.02 & 12.8 \\
\hline Pro & 1.67 & 6.0 & 1.94 & 6.0 & 2.22 & 6.1 & 2.49 & 6.2 & 2.77 & 6.3 & 3.04 & 6.4 & 3.32 & 6.5 \\
\hline Ser & -1.06 & 5.5 & -0.79 & 5.6 & -0.51 & 5.6 & -0.23 & 5.7 & 0.05 & 5.8 & 0.32 & 5.9 & 0.60 & 6.0 \\
\hline Tyr & -0.22 & 3.2 & 0.06 & 3.2 & 0.34 & 3.1 & 0.62 & 3.1 & 0.91 & 3.1 & 1.19 & 3.1 & 1.47 & 3.1 \\
\hline $\mathrm{SSE}^{2}$ & 10,205 & & 10,272 & & 10,380 & & 10,526 & & 10,707 & & 10,921 & & 11,164 & \\
\hline
\end{tabular}

${ }^{1} \mathrm{RMSE}=$ Root mean square prediction error.

${ }^{2} \mathrm{SSE}=$ Error sum of squares. 

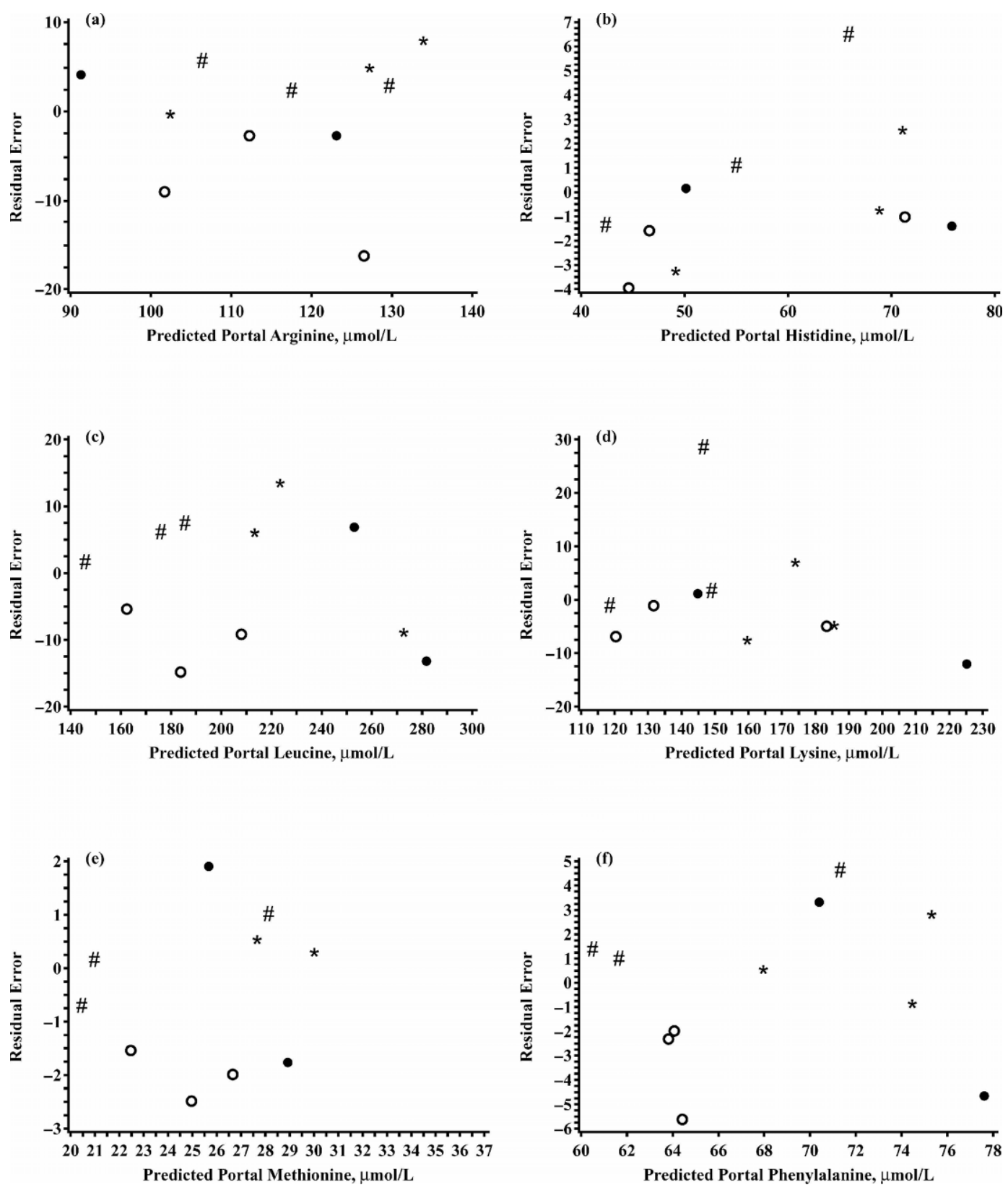

Figure 3. Residual errors (observed - predicted, $\mu \mathrm{mol} / \mathrm{L}$ ) for predictions of portal concentrations of Arg, His, Leu, Lys, Met, and Phe when equation (1) was fitted to the observed data where variable amounts of casein were infused abomasally $(\#=0 ; \circ=200 ; *=400$; and $\bullet=600 \mathrm{~g} / \mathrm{d})$.

to follow mass action (Hanigan et al., 1998b), and the modeling work herein suggests that the PDV also acted via mass action (Figure 5). Thus, for both the PDV and liver, there was no evidence for alterations in rate parameters for removal of AA as supply changes. The observed linear increase in arterial concentrations of blood urea supports this conclusion. Of course, these observations do not rule out changes in AA affinity or capacity in peripheral tissues as other dietary inputs are manipulated, e.g., energy status.
The responses of net PDV and liver metabolite fluxes were more variable when analyzed with a classical linear statistical model. This can be attributed in part to the smaller number of observations obtained, the inherent biological variability of these measurements, and variability due to factors not explicitly considered in the statistical model. In addition, net flux rates reflect changes in both AA absorption from basal and infused protein and total usage. Accommodation of arterial concentration and blood flow variation via use of equation 

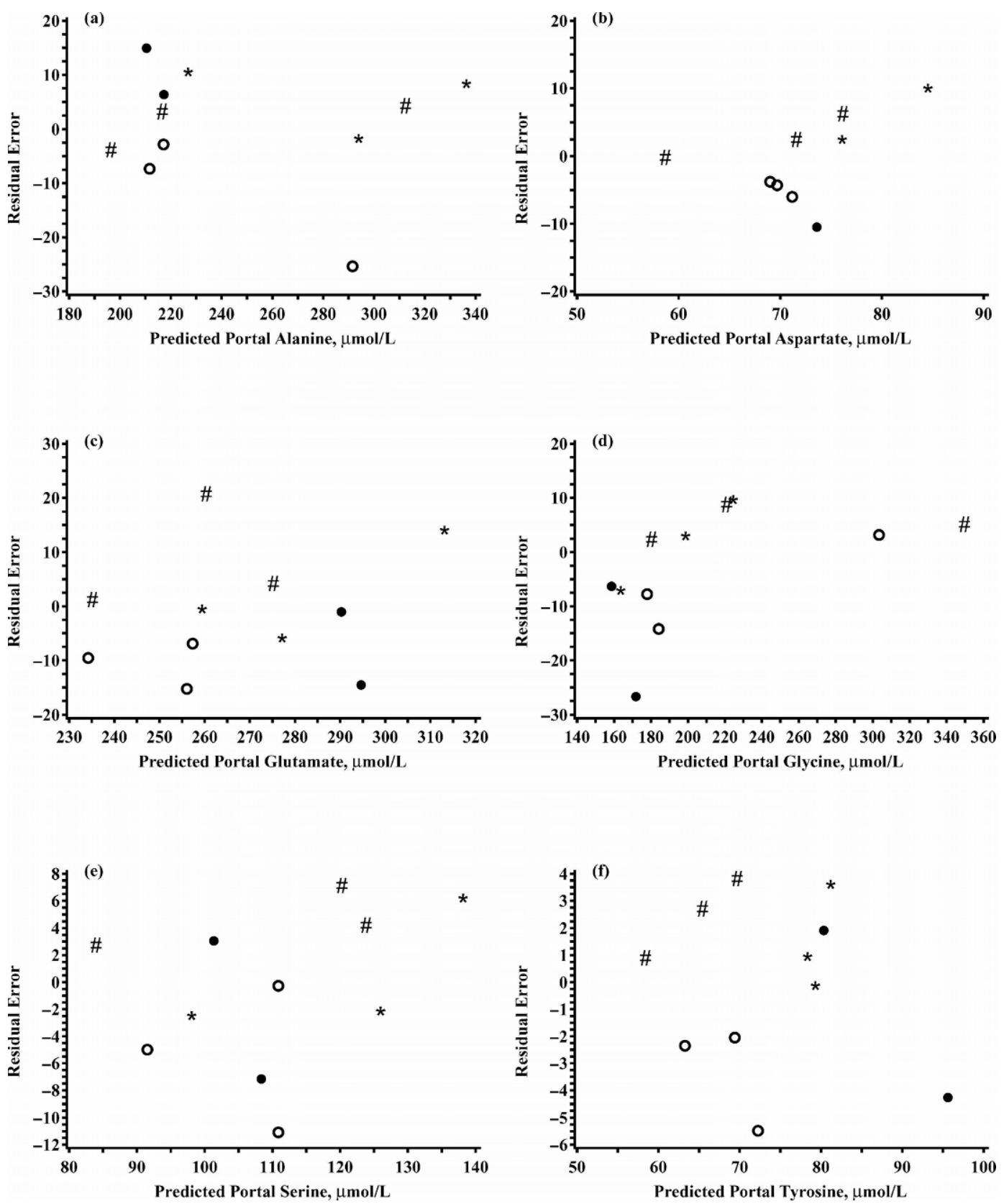

Figure 4. Residual errors (observed - predicted, $\mu \mathrm{mol} / \mathrm{L}$ ) for predictions of portal concentrations of Ala, Asp plus Asn (labeled as aspartate), Glu plus Gln (labeled as Glu), Gly, Ser, and Tyr when equation (1) was fitted to the observed data where variable amounts of casein were infused abomasally ( $\#=0 ; \circ=200 ; *=400$; and $\bullet=600 \mathrm{~g} / \mathrm{d})$.

(1) supports linear use of AA by PDV with respect to total arterial and luminal supply (Figure 3, Figure 5, and Table 14). Despite a near doubling in portal concentrations of some AA, there were no indications of nonlinear responses with respect to AA supply, as evidenced by a lack of systematic patterns in residual errors (Figures 3 and 4). Although portal fluxes tended to segregate by treatment group, significant variation exists, as demon- strated for His where portal concentrations for 2 control observations and 3 observations from the 200 - and 400$\mathrm{g} / \mathrm{d}$ infusion treatments were greater than the portal concentration for one of the observations from the 600$\mathrm{g} / \mathrm{d}$ treatment. This variation is likely due to amonganimal variation in blood flow, DMI, and arterial concentrations, none of which are accommodated in the statistical model. Given an adequate number of observations, 
Table 13. Potential net losses of protein and nitrogen in feces and at the ileum where maximal proportions of total portal-drained viscera amino acid use secreted into the rumen and small intestine and appearing at the ileum as endogenous protein or nitrogen were varied $(0.8,0.6$, or 0.4$)$. Values are expressed as the mean (SE). Endogenous flows were predicted from essential amino acids (EAA) use as defined by equation 4 considering all EAA or all EAA excepting lysine.

\begin{tabular}{llrrr}
\hline & \multicolumn{1}{l}{$\begin{array}{l}\text { Total } \\
\text { (feces) }\end{array}$} & \multicolumn{1}{c}{0.8} & \multicolumn{1}{c}{0.6} & \multicolumn{1}{c}{0.4} \\
\hline All EAA & & & & \\
$\quad$ Endogenous protein (g/d) & $84.0(5.1)$ & $67.2(4.1)$ & $50.4(3.1)$ & $33.6(2.0)$ \\
Endogenous protein N (g/d) & $12.4(0.8)$ & $9.9(0.6)$ & $7.5(0.5)$ & $5.0(0.3)$ \\
\% of ileal flow & $\ldots$ & $12.3(0.5)$ & $9.5(0.4)$ & $6.5(0.3)$ \\
$\quad$ Apparent small intestine protein digestibility (\%) & $\ldots$ & $80.2(0.2)$ & $80.8(0.2)$ & $81.4(0.2)$ \\
All EAA excepting lysine & $\ldots$ & & & \\
Endogenous protein (g/d) & $124(4.4)$ & $99.2(3.5)$ & $74.4(2.7)$ & $49.6(1.8)$ \\
Endogenous protein N (g/d) & $18.4(0.7)$ & $14.7(0.5)$ & $11.0(0.4)$ & $7.3(0.3)$ \\
\% of ileal flow & $\ldots$ & $17.2(0.5)$ & $13.5(0.4)$ & $9.4(0.3)$ \\
Apparent small intestine protein digestibility (\%) & $\ldots$ & $79.0(0.2)$ & $79.9(0.1)$ & $80.8(0.1)$ \\
\hline
\end{tabular}

they could be included in the statistical model as covariates, although one must be cognizant of nonlinear relationships such as exist between PDV usage and portal blood flow [equation (1)].

As stated previously, net flux of metabolites across the splanchnic tissues equals the sum of their simultaneous unidirectional release into venous blood and removal from arterial blood. Therefore, any change in use from arterial blood that accompanied an increase in absorption and arterial concentration would mask the observed change in unidirectional release into venous blood. Thus, in the present study, increases in absorption and arterial concentration of a number of AA were apparently accompanied by increases in their removal from arterial blood, which minimized measured changes in net release. This is consistent with a previous study where increases in net PDV release of $\alpha$-amino $\mathrm{N}$ only accounted for from 26 to $30 \%$ of the casein AA N infused into the abomasum of steers (Guerino et al., 1991). It is also consistent with the modeling observations wherein the assumption of equal affinity for arterial and absorbed AA did not result in any apparent bias in predictions (Figure 3 and Table 14). In addition, absorbed AA may have been catabolized during their absorption by intestinal enterocytes, but a substantial loss via this route would not explain the increases in arterial concentration observed. Amino acid removal by the PDV was relatively small on a fractional basis (Table 14) as compared with the udder but comparable to that of the liver (Hanigan et al., 1998b). However, because blood flow is significantly greater than for the udder, AA supply and subsequent removal is great. Total PDV use of AA averaged $24 \%$ of the mean predicted absorption from the intestinal tract. The mean for EAA use was $20 \%$ of the amount absorbed, with a range of $2.4 \%$ for Lys to $34 \%$ for His. These percentages are somewhat less than those observed by MacRae et al. (1997a) and Tagari and Bergman (1978) in nonlactating sheep, in part reflecting the use of AA for milk protein synthesis in the present study. Conversion of absorbed protein to milk protein was approximately $27 \%$. Thus, of the $73 \%$ of absorbed AA not converted to milk protein, slightly more than a third of the loss can be attributed to PDV use (24\% PDV/73\% postabsorptive). Net hepatic use was generally as great or greater than PDV use (Table 9 and Table 14), suggesting that greater than two-thirds of postabsorptive losses of EAA could be accounted for by splanchnic use. Although mammary tissue is able to catabolize a number of $\mathrm{AA}$, net catabolism of total $\mathrm{AA}$ appears to be small (Hanigan et al., 2001b) suggesting that the remaining losses occur primarily in other peripheral tissues such as muscle and skin (Lobley et al., 1997, 2000).

In the present study, arterial supply accounted for $69 \%$ of the total measured and estimated supply of AA to the PDV. Arterial supply of Met (21\%) and Phe (41\%) accounted for the smallest percentage of total PDV supply, whereas arterial supply accounted for a much larger quantity of the total availability of the branched-chain AA (80, 82, and $92 \%$ for Leu, Ile, and Val, respectively). This in part reflects the fact that the catabolism of BCAA largely occurs in extrahepatic tissues (Lobley et al., 2003), which is consistent with the observed greater increases in arterial concentrations of BCAA as infusion rate was increased. Thus, a significant proportion of total PDV use is apparently derived from arterial supplies. This is problematic from an experimental point if one is interested in deriving first-pass use during absorption. Any such attempts must consider the large proportion of supply provided by arterial blood and any potential changes in that supply due to recycling during the experiment. The first challenge can be overcome by increasing the infusion rate; however, such a strategy likely ensures large increases in recycling such that the anticipated fractional increase in absorbed supply with respect to total supply is not achieved. Such a prediction is consistent with previous observations (Aikman et al., 2002). 
Table 14. Observed mean fluxes, concentrations, and derived model parameters with assumed digestion coefficients for ruminally derived and infused nonammonia nitrogen of 0.8 and 0.95 , respectively, and a maximal proportion of portal-drained visceral amino acid use secreted into the small intestine and appearing at the ileum as endogenous protein of $60 \%$ (see Table 13). Endogenous secretions were calculated using all essential amino acids.

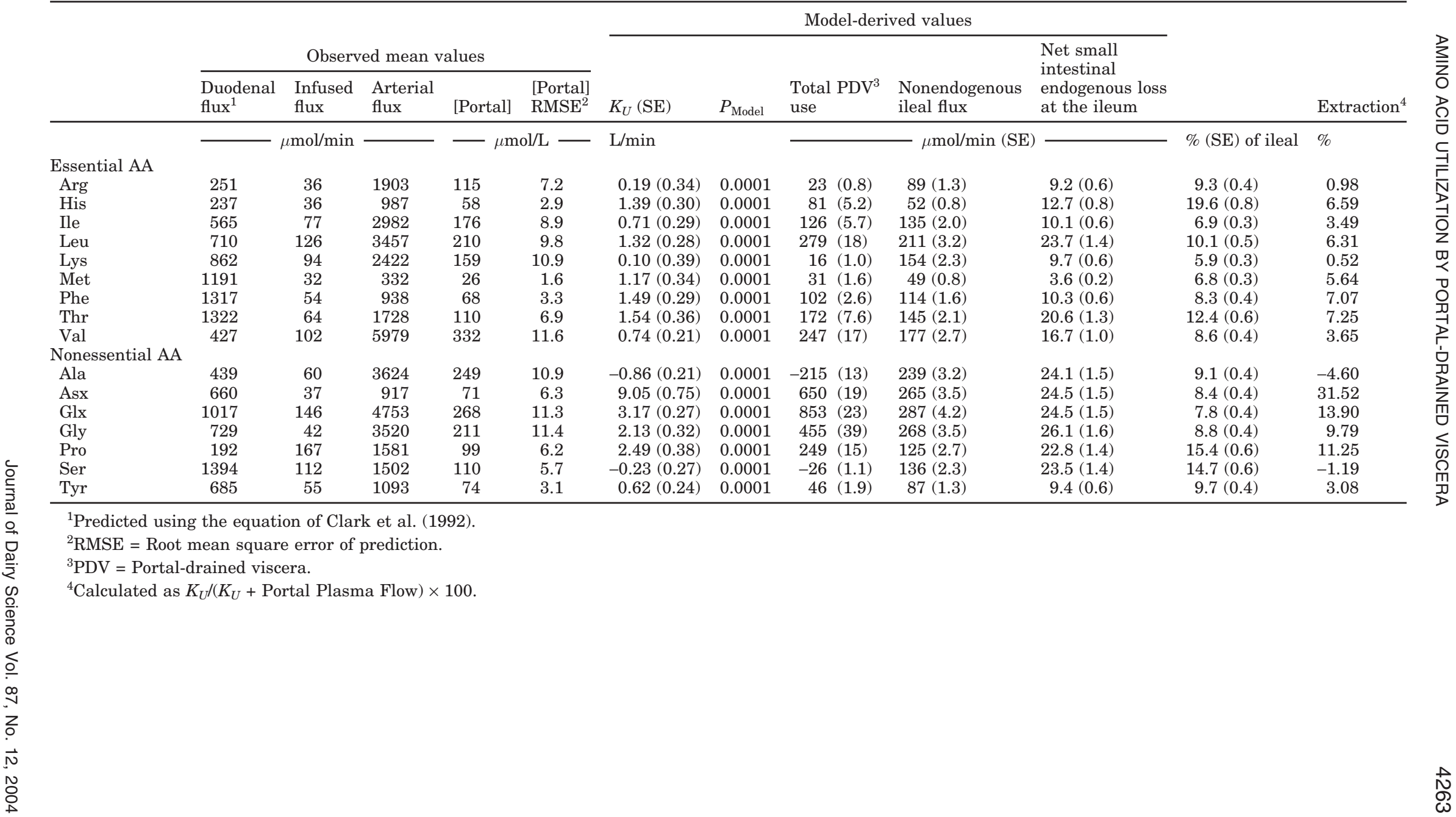




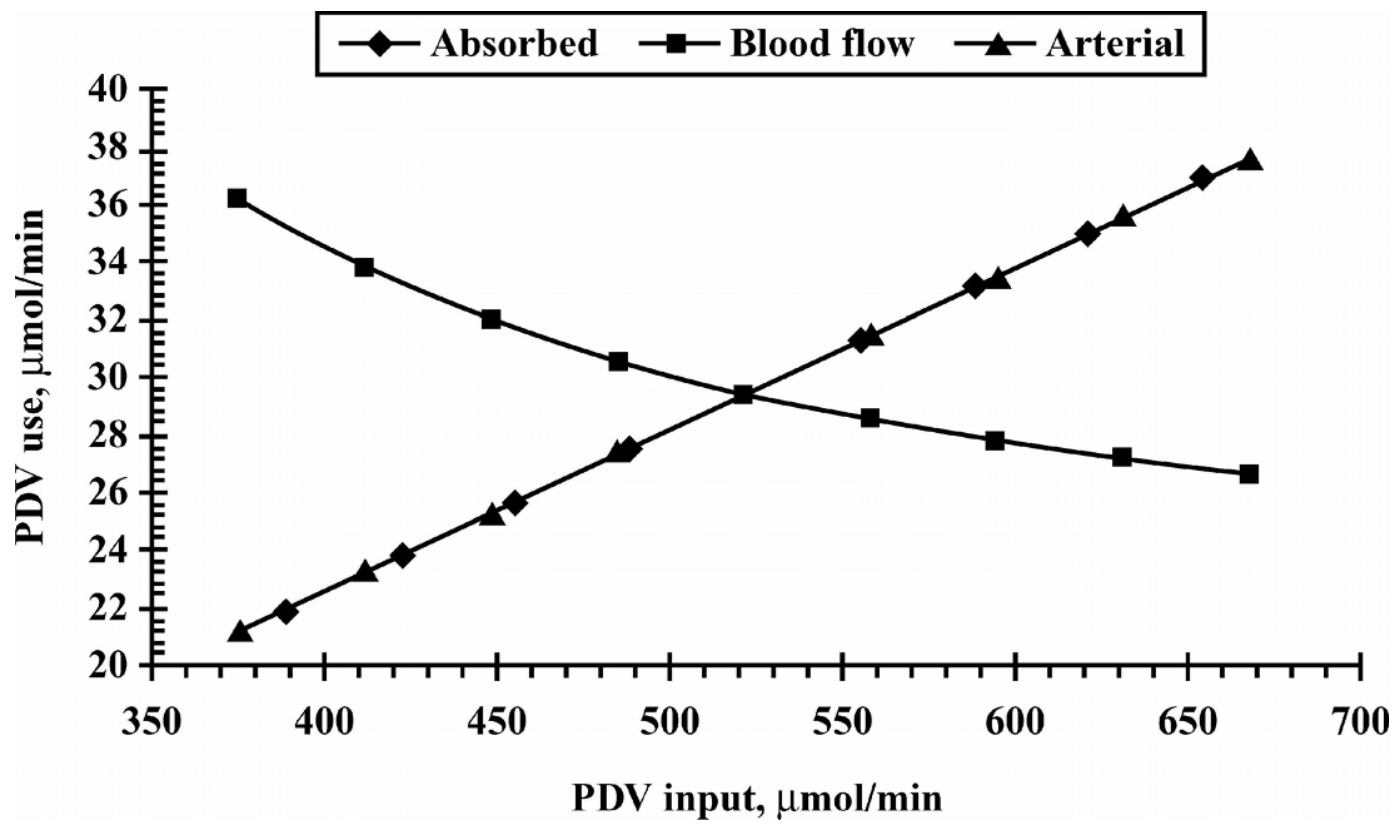

Figure 5. Predicted portal-drained viscera (PDV) removal of Met as PDV inputs (absorbed Met flux, arterial blood flow, or arterial Met concentration) were varied independently. $\mathrm{K}_{\mathrm{u}}$ was set to 1.17 . Mean reference inputs as summarized in Table 14 yielded a PDV input of $569 \mu \mathrm{mol} / \mathrm{min}$, which is the point of intersection for the 3 lines.

Of the AA removed by PDV, a significant fraction is apparently catabolized given the excess of PDV removal with respect to supportable endogenous losses into the gut lumen (Table 13). Nitrogen derived from such catabolism was apparently transferred into Gln, as evidenced by a significant positive slope for Gln release and numerical reductions in Glu release from PDV (Table 8), and used for Ala synthesis (Table 14).

Changes in portal blood flow that might occur as dietary energy supply changes (Seal and Reynolds, 1993) have implications with respect to net use of AA from arterial supplies (Figure 5). As blood flow increases, arterial input of AA increases, thus delivering more AA to the tissue bed. However, portal vein flow also increases. The latter change results in increased rates of venous removal of AA from the tissue bed. As the PDV is generally a net producer of AA via absorption, the increased rate of removal results in a fall in extracellular AA concentrations and thus a reduction in net PDV use. Thus, the absolute loss of AA to PDV on a daily basis would be expected to decline on a high-energy diet as compared with one of lesser energy value. Such a decline may be magnified or mitigated by changes in affinity or capacity of other peripheral tissues in response to the change in energy status. However, in the absence of such changes, mass-action kinetics would suggest that decreased removal by PDV in association with increased energy supply should result in greater AA availability for productive purposes. This may partially explain observed increases in protein output in milk in association with increased energy supply at a given level of protein intake (Hanigan et al., 1998a), although one cannot rule out other changes in peripheral tissue affinity or capacity resulting from changes in endocrine status.

In current factorial requirement schemes, the PDV and hepatic tissues would be considered as part of the maintenance component where maintenance is generally considered a constant function of body size (NRC, 2001). As milk production increases from zero, additional AA are required to support milk protein synthesis. Given the observation of mass-action kinetics at the splanchnic tissues, the additional supply of AA required in support of milk protein synthesis would result in greater daily losses of AA at the splanchnic tissues. Consequently, the assumption of a fixed maintenance cost as milk production or any other productive function varies would apparently result in errors of prediction. This may partially explain the significantly lower observed partial efficiencies of nitrogen conversion to milk (Hanigan et al., 1998a) as compared with that predicted from current models (NRC, 1989).

\section{Parameter Estimation}

Small extraction rates in combination with large arterial fluxes and use of AA from arterial supplies present a challenge in deriving model parameters. Although previous efforts have helped to demonstrate PDV use of AA 
(Tagari and Bergman, 1978; MacRae et al., 1997b), they were not designed to evaluate kinetic responses to varying AA supply. Weekes and Webster (1975) used variable infusion rates to determine the net kinetics of propionate production and use by PDV. However, that approach cannot be used to derive estimates for AA because arterial flux and use is significant (see Figure 2a). The method could be adapted to include measurements of arterial influx as an independent variable, although such an approach would not accurately reflect the effects of changes in blood flow (Figure 5). The model presented here more appropriately represents blood flow effects and allows for future integration into more holistic models of tissue metabolism (Hanigan et al., 2001b, 2003). However, it has the same limitations in terms of parameter estimation, in that estimation of absorption rates in the basal state and fractional use of AA require data with either a broader range of inputs or less variance than that provided in this experiment (Figure $2 b$ ). In the absence of such range or precision, PDV use and basal intestinal absorption rates cannot both be uniquely determined, and one of the parameters must be measured independently.

Assuming that protein infusions cannot be increased enough to create the needed variation in inputs to PDV, it seems necessary to plan for sampling of at least duodenal or omasal (Huhtanen et al., 1997a) flows when collecting data to further parameterize this model. Ideally, duodenal (or omasal) protein flow in the absence of infusion would be measured before each level of infusion to account for any variation in flow with respect to time. Because dietary factors and intake can be more tightly controlled than other animal factors (i.e., blood flow and arterial concentrations), the digestibility measurements could be made in a second set of animals and the mean digestion coefficients used for derivation of the remaining PDV model parameters.

\section{Milk Protein Responses}

The effect of casein infusion on milk and milk protein yield in the present study was comparable to previous studies (Huhtanen et al., 1997b; Hanigan et al., 1998a; Aikman et al., 2002; Khalili and Huhtanen, 2002). Recovery of infused protein as increased milk protein secretion was greatest at the lowest level of infusion, as noted in a previous review of published observations (Aikman et al., 2002). However, in contrast to a number of these previous studies, increased milk protein yield in the present study was not associated with an increase in milk protein concentration, but was achieved totally through increased milk yield. In the present study, the largest increase in milk protein yield was measured at the lowest level of infusion. Similar curvilinear responses to incre- mental infusion of casein protein, at levels varying from 84 to $654 \mathrm{~g} / \mathrm{d}$, have been reported previously (Konig et al., 1984; Whitelaw et al., 1986; Choung and Chamberlain, 1993; Guinard et al., 1994; Choung and Chamberlain, 1995); thus, the response may be related to more than AA supply per se. As in the present study, milk protein secretion response to incremental levels of casein infusion in those previous studies was greatest at about or below $200 \mathrm{~g}$ of daily casein infusion (135 to $192 \mathrm{~g}$ protein/d).

The curvilinear response of milk protein output to casein infusion suggests that AA supply was not the only factor limiting milk protein output. Energy supply can limit milk production (Moallem et al., 2000). Although casein infusion results in the provision of additional energy, the relative increase in energy with respect to basal dietary supply would not be nearly as great as the increase in AA supply relative to basal conditions, i.e., the ratio of protein to energy was increasing as increments of casein were infused. Limitations on milk protein output may occur simply due to inadequate or inappropriate energy substrate supply, or they may be elicited by endocrine changes that determine the maximal mammary synthetic capacity (Knight and Wilde, 1993) and propensity of the gland for milk protein synthesis. As the maximal rate of milk protein synthesis is approached, responses to incremental increases in substrate supply would be expected to be curvilinear. Bequette et al. (2000) have demonstrated in goats that mammary AA transport activity changes so that mammary AA supply matches needs, i.e., excess AA results in inhibition of transport activity and a deficiency results in stimulation of transport activity. Thus, as maximal mammary synthetic capacity is approached, incremental removal of AA from blood with respect to concentration changes would decline, resulting in increased recycling of circulating AA to the splanchnic tissues. A linear fraction of these recycled AA would be removed and catabolized in the splanchnic tissues (Hanigan et al., 1998b) (Figure 3), which is consistent with the observed increases in urea concentration (Table 6). Thus fractional clearance by the splanchnic tissues would have increased as the infusion rate increased, due not to a change in splanchnic removal activity per se, but rather to the failure of mammary and other peripheral tissues to remove the added increments of AA.

\section{Endogenous Protein Secretions}

All EAA were apparently taken up in quantities adequate to support at least some net endogenous protein secretions. Using the endogenous AA composition reported by Storm et al. (1983) and the predicted net removals in Table 14, one can calculate a maximal loss of 
AA in endogenous protein supported by each EAA. In this manner, the maximal flux of protein appears to be limited by Lys availability. Using the flux predicted by Lys removal and assuming that ileal endogenous protein flow represents $60 \%$ of total endogenous losses ( $40 \%$ loss into the large intestine), net losses of EAA would be adequate to support $7.5 \mathrm{~g} / \mathrm{d}$ endogenous $\mathrm{N}$ loss at the ileum and $12.4 \mathrm{~g} / \mathrm{d}$ in the feces (Table 13). Calculating maximal protein flux using this limiting AA calculation has been reported to underestimate the flux due to variations in the individual measurements, i.e., the calculation is sensitive to underestimates of each AA but not to overestimates, resulting in a mean underprediction (Hanigan et al., 2000). If Lys is not considered as limiting, endogenous $\mathrm{N}$ loss could be as great as $11 \mathrm{~g}$ of $\mathrm{N} / \mathrm{d}$ at the ileum (13.5\% of total ileal $\mathrm{N}$ flow) and $18.4 \mathrm{~g}$ of N/d in the feces. The latter estimate is only slightly less than that reported by Ouellet et al. (2002) for lactating dairy cows and the $15 \%$ value deduced by Sutton and Reynolds (2002). Sheep have been reported to have a much higher percentage of ileal flow, represented by endogenous secretions with values ranging from 33 to $50 \%$ (LammersWienhoven et al., 1997; Van Bruchem et al., 1997; Sandek et al., 2001). However, none of these latter studies corrected for ${ }^{15} \mathrm{~N}$-urea incorporation into microbes in the rumen as was undertaken by Ouellet et al. (2002). Because this represents approximately half of the apparent endogenous flow, the observations in sheep also may be consistent with the values reported here and by Ouellet et al. (2002). When making these calculations, one must be cognizant of the potential release of AA as peptides into the portal vein (Remond et al., 2000). Release of any EAA in peptide form would negatively affect the amount of EAA apparently available for synthesis of endogenous secretions.

The assumption regarding the proportion of the total PDV net loss arriving at the ileum is important in ascertaining the maximal loss supported. However, it has no bearing on parameter estimation for PDV use. Whereas the gut tissue mass and surface area represented by gut tissue preceding the ileum is greater than $60 \%$ of the total gut mass (Gibb et al., 1992), significant reabsorption of secreted protein occurs prior to the ileum with little reabsorption after that point. Thus, a value of 0.6 seems reasonable.

The apparent shortage of Lys may also reflect the assumptions regarding duodenal NAN digestibility. Berthiaume et al. (1996) observed an apparent small intestinal Lys digestibility of $75 \%$, whereas the mean EAA digestibility was 66\%. Lebzien and Rohr (1994) also observed greater Lys digestibility than the average of all AA, which was $83 \%$. Thus, the assumed common digestibility used herein for all AA may be an underestimate for Lys. Any increases in digestibility would result in a greater absorption of Lys and a greater total uptake of Lys by PDV, and thus in more potential production of endogenous proteins.

Given the assumed losses of endogenous protein at the ileum, the expected true small intestinal digestibility for infused plus duodenal NAN of $81.5 \%$ [ $(300 \times 0.95+2745$ $\times 0.80) /(2745+300)=0.815]$ equates to an apparent digestibility of $80 \%$, which is greater than that reported by Berthiaume et al. (1996) and slightly more than the average (75\%) from a review of published data in lactating dairy cows reported by Sutton and Reynolds (2002), but generally consistent with the NRC (2001) and observations of Lebzien and Rohr (1994). If the true digestibility were $85 \%$, then available Lys would triple (Table 12), resulting in a significant increase in the amount of endogenous protein that could be secreted and appear at the ileum and a reduction in nonendogenous protein arriving at the ileum. The combination of the 2 would have a significant impact on the proportion of ileal protein flow, represented by endogenous proteins and the difference between apparent and true small intestinal digestibilities. As such, the evaluation of both the amount of endogenous loss at the ileum and the inherent digestibility of dietary NAN are important factors in deriving a more complete model of PDV AA metabolism.

In summary, net PDV metabolism of AA can be derived given observations of duodenal outflow of protein from the rumen, knowledge of duodenal and infused protein digestibility, graded infusions of a source protein, and portal and arterial flux measurements. If arterial AA concentrations can be maintained at relatively low levels and dietary protein input is low, it may be possible to derive the absorbed AA values in the noninfused state and fractional use by PDV if a large enough range of infusion levels can be used, i.e., apparently greater than $1.2 \mathrm{~kg}$ of protein/d in a dairy cow. Net losses of AA to catabolism in the PDV during absorption apparently are not very large. However, the combination of net losses during absorption and losses from AA recycled to the tissue in arterial blood are significant and do influence apparent AA absorption. Ignoring this impact would lead to systematic errors of prediction for AA availability for peripheral tissue use.

\section{ACKNOWLEDGMENTS}

This work was funded by a consortium of governmental and industrial organizations, including the Department for Environment, Food and Rural Affairs, the Biotechnology and Biological Science Research Council, Purina Mills LLC, the Milk Development Council of England, Scotland and Wales, and NUTRECO Inc. The comments and support of N. E. Smith are greatly appreciated. The dedicated and expert support of the tech- 
nical staff of the CEDAR Metabolism Unit in the daily care and management of cows and the technical contributions of K. Firth are gratefully acknowledged.

\section{REFERENCES}

Aikman, P. C., C. K. Reynolds, D. J. Humphries, D. E. Beever, and J. C. MacRae. 2002. Milk protein response to abomasal or mesenteric vein essential amino acid infusion in lactating dairy cows. J. Dairy Sci. 85:1079-1084.

Argenzio, R. A. 1993. Digestion and absorption of carbohydrate, fat, and protein. Pages 362-375 in Duke's Physiology of Domestic Animals. J. Swenson, ed. Comstock Publishing Association, Ithaca, NY.

Benson, J. A., C. K. Reynolds, P. C. Aikman, B. Lupoli, and D. E. Beever. 2002. Effects of abomasal vegetable oil infusion on splanchnic nutrient metabolism in lactating dairy cows. J. Dairy Sci. 85:1804-1814.

Bequette, B. J., M. D. Hanigan, A. G. Calder, C. K. Reynolds, G. E. Lobley, and J. C. MacRae. 2000. Amino acid exchange by the mammary gland of lactating goats when histidine limits milk production. J. Dairy Sci. 83:765-775.

Berthiaume, F., P. Moghe, M. Toner, and M. Yarmush. 1996. Effect of extracellular matrix topology on cell structure, function, and physiological responsiveness: Hepatocytes cultured in a sandwich configuration. FASEB 10:1471-1484.

Berthiaume, R., P. Dubreuil, M. Stevenson, B. W. McBride, and H. Lapierre. 2001. Intestinal disappearance and mesenteric and portal appearance of amino acids in dairy cows fed ruminally protected methionine. J. Dairy Sci. 84:194-203.

Cant, J. P., and B. W. McBride. 1995. Mathematical analysis of the relationship between blood flow and uptake of nutrients in the mammary glands of a lactating cow. J. Dairy Res. 62:405-422.

Choung, J. J., and D. G. Chamberlain. 1993. Effects on milk yield and composition of intra-abomasal infusions of sodium caseinate, an enzymic hydrolysate of casein or soya-protein isolate in dairy cows. J. Dairy Res. 60:133-138.

Choung, J. J., and D. G. Chamberlain. 1995. Effects of abomasal infusions of sodium caseinate and of casein hydrolysates varying in the relative proportions of peptides and free amino acids on milk production in dairy cows. J. Dairy Res. 62:423-429.

Clark, J. H., T. H. Klusmeyer, and M. R. Cameron. 1992. Microbial protein synthesis and flows of nitrogen fractions to the duodenum of dairy cows. J. Dairy Sci. 75:2304-2323.

Detweiler, D. K. 1984. Control mechanisms of the circulatory system. Pages 163-191 in Duke's Physiology of Domestic Animals. J. Swenson, ed. Comstock Publishing Association, Ithaca, NY.

Dijkstra, J., H. D. Neal, D. E. Beever, and J. France. 1992. Simulation of nutrient digestion, absorption and outflow in the rumen: Model description. J. Nutr. 122:2239-2256.

Gibb, M. J., W. E. Ivings, M. S. Dhanoa, and J. D. Sutton. 1992. Changes in body components of autumn-calving Holstein-Friesian cows over the first 29 weeks of lactation. Anim. Prod. 55:339-360.

Guerino, F., G. B. Huntington, and R. A. Erdman. 1991. The net portal and hepatic flux of metabolites and oxygen consumption in growing beef steers given postruminal casein. J. Anim. Sci. 69:387-395.

Guinard, J., H. Rulquin, and R. Verite. 1994. Effect of graded levels of duodenal infusions of casein on mammary uptake in lactating cows. I. Major nutrients. J. Dairy Sci. 77:2221-2231.

Hanigan, M. D., J. P. Cant, D. C. Weakley, and J. L. Beckett. 1998a. An evaluation of postabsorptive protein and amino acid metabolism in the lactating dairy cow. J. Dairy Sci. 81:3385-3401.

Hanigan, M. D., L. A. Crompton, B. J. Bequette, J. A. N. Mills, and J. France. 2001a. Modelling mammary metabolism in the dairy cow to predict milk constituent yield, with emphasis on amino acid metabolism and milk protein production: Model evaluation. J. Theor. Biol. 217:311-330.

Hanigan, M. D., L. A. Crompton, J. A. Metcalf, and J. France. 2001b. Modelling mammary metabolism in the dairy cow to predict milk constituent yield, with emphasis on amino acid metabolism and milk protein production: Model construction. J. Theor. Biol. 213:223-239.
Hanigan, M. D., L. A. Crompton, C. K. Reynolds, D. Wray-Cahen, M. A. Lomax, and J. France. 2003. An integrative model of amino acid metabolism in the liver of the lactating dairy cow. J. Theor. Biol. 228:271-289.

Hanigan, M. D., J. France, L. A. Crompton, and B. J. Bequette. 2000. Evaluation of a representation of the limiting amino acid theory for milk protein synthesis. Pages 127-144 in Modelling Nutrient Utilization in Farm Animals. J. P. McNamara, J. France, and D. E. Beever, ed. CABI Publishing, Wallingford, UK.

Hanigan, M. D., J. France, D. Wray-Cahen, D. E. Beever, G. E. Lobley, L. Reutzel, and N. E. Smith. 1998b. Alternative models for analyses of liver and mammary transorgan metabolite extraction data. Br. J. Nutr. 79:63-78.

Huhtanen, P., P. G. Brotz, and L. D. Satter. 1997a. Omasal sampling technique for assessing fermentative digestion in the forestomach of dairy cows. J. Anim. Sci. 75:1380-1392.

Huhtanen, P., A. Vanhatalo, and T. Varvikko. 1997b. Effects of abomasal infusions of histidine, leucine, and glucose on milk production in cows given grass silage based diets. J. Dairy Sci. 80:247.

Huntington, G. B. 1989. Hepatic urea synthesis and site and rate of urea removal from blood of beef steers fed alfalfa hay or a high concentrate diet. Can. J. Anim. Sci. 69:215-223.

Khalili, H., and P. Huhtanen. 2002. Effect of casein infusion in the rumen, duodenum or both sites on factors affecting forage intake and performance of dairy cows fed red clover-grass silage. J. Dairy Sci. 85:909-918.

Knight, C. H., and C. J. Wilde. 1993. Mammary cell changes during pregnancy and lactation. Livest. Prod. Sci. 35:3-19.

Konig, B. A., J. D. Oldham, and D. S. Parker. 1984. The effect of abomasal infusion of casein on acetate, palmitate and glucose kinetics in cows during early lactation. Br. J. Nutr. 52:319-328.

Korhonen, M., S. Ahvenjarvi, A. Vanhatalo, and P. Huhtanen. 2002a. Supplementing barley or rapeseed meal to dairy cows fed grassred clover silage. II. Amino acid profile of microbial fractions. J. Anim. Sci. 80:2188-2196.

Korhonen, M., A. Vanhatalo, and P. Huhtanen. 2002b. Evaluation of lsoleucine, leucine, and valine as a second-limiting amino acid for milk production in dairy cows fed grass silage diet. J. Dairy Sci. 85:1533-1545.

Lammers-Wienhoven, S. C. W., J. Voigt, L. Ram, J. Van Bruchem, J. Ketelaars, and S. Tamminga. 1997. Effect of cell walls, dry matter and protein supply on endogenous nitrogen flow in the small intestine of sheep. J. Anim. Physiol. Anim. Nutr. 78:129-140.

Lebzien, P., and K. Rohr. 1994. Determination of true digestibility of amino acids from the small intestine of dairy cows. Arch. Tierernahr. 45:355-362.

Lobley, G. E., J. Lee, J. H. Edwards, and P. M. Harris. 1997. A comparison of changes in whole body and skin amino acid metabolism of sheep in response to $24 \mathrm{~h}$ continuous infusions of variants of insulinlike growth factor 1. Can. J. Anim Sci. 77:695-706.

Lobley, G. E., X. Z. Shen, G. W. Le, D. M. Bremner, E. Milne, A G. Calder, S. E. Anderson, and N. Dennison. 2003. Oxidation of essential amino acids by the ovine gastrointestinal tract. Br. J. Nutr. 89:617-629

Lobley, G. E., K. D. Sinclair, C. M. Grant, L. Miller, D. Mantle, A. G. Calder, C. C. Warkup, and C. A. Maltin. 2000. The effects of breed and level of nutrition on whole-body and muscle protein metabolism in pure-bred Aberdeen Angus and Charolais beef steers. Br. J. Nutr. 84:275-284.

MacRae, J. C., L. A. Bruce, D. S. Brown, and A. G. Calder. 1997a. Amino acid use by the gastrointestinal tract of sheep given lucerne forage. Am. J. Physiol. 273:G1200-G1207.

MacRae, J. C., L. A. Bruce, D. S. Brown, D. A. H. Farningham, and M. Franklin. 1997b. Absorption of amino acids from the intestine and their net flux across the mesenteric- and portal-drained viscera of lambs. J. Anim. Sci. 75:3307-3314.

Metcalf, J. A., L. A. Crompton, D. Wraycahen, M. A. Lomax, J. D. Sutton, D. E. Beever, J. C. MacRae, B. J. Bequette, and F. Backwell. 1996. Responses in milk constituents to intravascular administration of two mixtures of amino acids to dairy cows. J. Dairy Sci. 79:1425-1429. 
Mgheni, D. M., T. Hvelplund, and M. R. Weisbjerg. 1994. Intestinal digestibility of rumen undegraded dietary protein from tropical roughages estimated by the mobile bag technique. Acta Agric. Scand. A. Anim. Sci. 44:230-235.

Moallem, U., Y. Folman, and D. Sklan. 2000. Effects of somatotropin and dietary calcium soaps of fatty acids in early lactation on milk production, dry matter intake, and energy balance of high-yielding dairy cows. J. Dairy Sci. 83:2085-2094.

Mupeta, B., M. R. Weisbjerg, T. Hvelplund, and J. Madsen. 1997. Digestibility of amino acids in protein rich tropical feeds for ruminants estimated with the mobile bag technique. Anim. Feed Sci. Technol. 69:271-280.

National Research Council. 1989. Nutrient Requirements of Dairy Cattle. 6th ed. Natl. Acad. Press, Washington, DC.

National Research Council. 2001. Nutrient Requirements of Dairy Cattle, 7th rev. ed. Natl. Acad. Press, Washington, DC.

O'Connor, J. D., C. J. Sniffen, D. G. Fox, and W. Chalupa. 1993. A net carbohydrate and protein system for evaluating cattle diets. IV. Predicting amino acid adequacy. J. Anim. Sci. 71:1298-1311.

O’Mara, F. P., J. J. Murphy, and M. Rath. 1998. Effect of amount of dietary supplement and source of protein on milk production, ruminal fermentation, and nutrient flows in dairy cows. J. Dairy Sci. 81:2430-2439.

O'Mara, F. P., G. K. Stakelum, P. Dillon, J. J. Murphy, and M. Rath. 1997. Rumen fermentation and nutrient flows for cows fed grass and grass supplemented with molassed beet pulp pellets. J. Dairy Sci. 80:2466-2474.

Ouellet, D. R., M. Demers, G. Zuur, G. E. Lobley, J. R. Seoane, J. V. Nolan, and H. Lapierre. 2002. Effect of dietary fiber on endogenous nitrogen flows in lactating dairy cows. J. Dairy Sci. 85:3013-3025.

Remond, D., L. Bernard, and C. Poncet. 2000. Free and peptide amino acid net flux across the rumen and the mesenteric- and portaldrained viscera of sheep. J. Anim. Sci. 78:1960-1972.

Reynolds, C. K., P. C. Aikman, B. Lupoli, D. J. Humphries, and D. E. Beever. 2003. Splanchnic metabolism of dairy cows during the transition from late gestation through early lactation. J. Dairy Sci. $86: 1201-1217$.

Reynolds, C. K., L. A. Crompton, K. Firth, D. Beever, J. Sutton, M. A. Lomax, D. Wray-Cahen, J. Metcalf, B. Bequette, F. R. C. Backwell, G. Lobley, and J. MacRae. 1995. Splanchnic and milk protein responses to mesenteric vein infusion of 3 mixtures of amino acids in lactating dairy cows. J. Anim. Sci. 73(Suppl. 1):274. (Abstr.)

Risau, W. 1995. Differentiation of endothelium. FASEB 9:926-933.

Rulquin, H., J. Guinard, and R. Verite. 1998. Variation of amino acid content in the small intestine digesta of cattle: Development of a prediction model. Livest. Prod. Sci. 53:1-13.
Russell, J. B., J. D. O'Connor, D. G. Fox, S. Van, and C. J. Sniffen. 1992. A net carbohydrate and protein system for evaluating cattle diets. I. Ruminal fermentation. J. Anim. Sci. 70:3551-3561.

Rutherfurd, S. M., and P. J. Moughan. 1998. The digestible amino acid composition of several milk proteins: Application of a new bioassay. J. Dairy Sci. 81:909-917.

Sandek, A., K. Krawielitzki, J. Kowalczyk, F. Kreienbring, U. Schonhusen, M. Gabel, T. Zebrowska, H. Hagemeister, and J. Voigt. 2001. Studies on N-metabolism in different gastro-intestinal sections of sheep using the digesta exchange technique. 2. Passage of endogenous nitrogen. J. Anim. Feed Sci. 10:605-618.

SAS/STAT User's Guide, Version 6. 1990. SAS Inst., Inc., Cary, NC.

Seal, C. J., and C. K. Reynolds. 1993. Nutritional implications of gastrointestinal and liver metabolism in ruminants. Nutr. Res. Rev. 6:185-208.

Sniffen, C. J., J. D. O'Connor, S. Van, D. G. Fox, and J. B. Russell. 1992. A net carbohydrate and protein system for evaluating cattle diets. II. Carbohydrate and protein availability. J. Anim. Sci. 70:3562-3577.

Statutory Instruments. 1982. Number 1144. Agriculture. The Feeding Stuffs (Sampling and Analysis) Regulations. Her Majesty's Stationary Office, London, UK.

Storm, E., D. S. Brown, and E. R. Orskov. 1983. The nutritive value of rumen micro-organisms in ruminants. 3 . The digestion of microbial amino and nucleic acids in, and losses of endogenous nitrogen from, the small intestine of sheep. Br. J. Nutr. 50:479-485.

Sutton, J. D., and C. K. Reynolds. 2002. Nutrients, digestion and absorption: Small intestine of lactating ruminants. Pages $2120-2127$ in Encyclopedia of Dairy Sciences. H. Roginski, J. W. Fuquay, and P. F. Fox, ed. Academic Press, New York, NY.

Tagari, H., and E. N. Bergman. 1978. Intestinal disappearance and portal blood appearance of amino acids in sheep. J. Nutr. 108:790-803.

Van Bruchem, J., J. Voigt, T. S. C. W. Lammers-Wienhoven, U. Schonhusen, J. J. M. H. Ketelaars, and S. Tamminga. 1997. Secretion and reabsorption of endogenous protein along the small intestine of sheep: Estimates derived from N-15 dilution of plasma nonprotein-N. Br. J. Nutr. 77:273-286.

Weekes, T. E. C., and J. F. Webster. 1975. Metabolism of propionate in the tissues of the sheep gut. Br. J. Nutr. 33:425-438.

Weisbjerg, M. R., T. Hvelplund, S. Hellberg, S. Olsson, and S. Sanne. 1996. Effective rumen degradability and intestinal digestibility of individual amino acids in different concentrates determined in situ. Anim. Feed Sci. Technol. 62:179-188.

Whitelaw, F. G., J. S. Milne, E. R. Orskov, and J. S. Smith. 1986. The nitrogen and energy metabolism of lactating cows given abomasal infusions of casein. Br. J. Nutr. 55:537-556. 